\title{
Increased antibacterial properties of indoline-derived phenolic Mannich bases
}

Tatu Rimpiläinen, ${ }^{a}$ Alexandra Nunes,,${ }^{b, c, d *}$ Rita Calado, ${ }^{b}$ Ana S. Fernandes, ${ }^{d}$ Joana Andrade, ${ }^{d}$ Epole Ntungwe, ${ }^{d}$ Gabriella Spengler, ${ }^{e}$ Nikoletta Szemerédi, ${ }^{e}$ João Rodrigues, ${ }^{a}$ João Paulo Gomes, ${ }^{a}$ Patricia Rijo, ${ }^{d, g}$ and Nuno R. Candeias ${ }^{a, h, *}$

a Faculty of Engineering and Natural Sciences, Tampere University, Korkeakoulunkatu 8, 33101 Tampere, Finland

${ }^{b}$ Department of Infectious Diseases, National Institute of Health, Avenida Padre Cruz, 1649-016 Lisboa, Portugal

' Faculty of Veterinary Medicine, Lusófona University, Campo Grande 376, 1749-024 Lisboa, Portugal

${ }^{d}$ CBIOS-Universidade Lusófona Research Center for Biosciences \& Health Technologies, Campo Grande 376, 1749-024 Lisboa, Portugal

e Department of Medical Microbiology and Immunobiology, Faculty of Medicine, University of Szeged, Dóm tér 10, 6720, Szeged, Hungary

${ }^{\mathrm{g}}$ Instituto de Investigação do Medicamento (iMed.ULisboa), Faculdade de Farmácia, Universidade de Lisboa, Av. Prof. Gama Pinto, 1649-003 Lisboa, Portugal

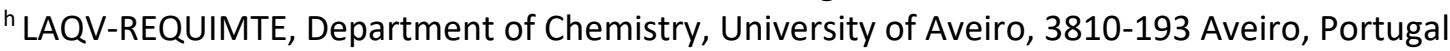

Email: alexandra.nunes@insa.min-saude.pt (A. N.); ncandeias@ua.pt (NRC)

\begin{abstract}
The search for antibacterial agents for the combat of nosocomial infections is a timely problem, as antibiotic-resistant bacteria continue to thrive. The effect of indoline substituents on the antibacterial properties of aminoalkylphenols was studied, leading to the development of a library of compounds with minimum inhibitory concentrations (MICs) as low as $1.18 \mu \mathrm{M}$. Two novel aminoalkylphenols were identified as particularly promising, after MIC and minimum bactericidal concentrations (MBC) determination against a panel of reference strain Gram-positive bacteria, and further confirmed against 40 clinical isolates (Staphylococcus aureus, S. epidermidis, Enterococcus faecalis, E. faecium, and Listeria monocytogenes). The same two aminoalkylphenols displayed low toxicity against two in vivo models (Artemia salina brine shrimp and Saccharomyces cerevisiae). The in vitro cytotoxicity evaluation (on human keratinocytes and human embryonic lung fibroblast cell lines) of the same compounds was also carried out. They demonstrated a particularly toxic effect on the fibroblast cell lines, with $\mathrm{IC}_{50}$ in the 1.7-5.1 $\mu \mathrm{M}$ range, thus narrowing their clinical use. The desired increase in the antibacterial properties of the alkylaminophenols, particularly indoline-derived phenolic Mannich bases, was reached by introducing an additional nitro group in the indolinyl substituent or by the replacement of a methyl by a bioisosteric trifluoromethyl substituent. Notably, the introduction of an additional nitro moiety did not confer added toxicity to the alkylaminophenols.
\end{abstract}

Keywords: antibacterials; alkylaminophenols; Gram-positive; nosocomial infections

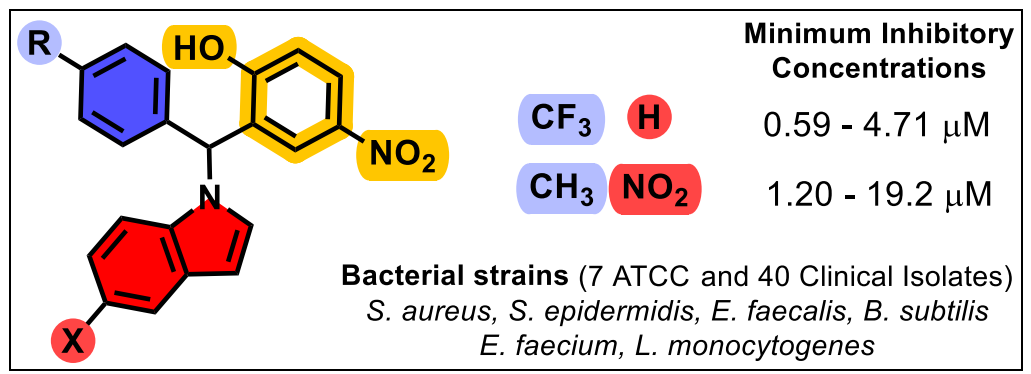




\section{Introduction}

The emergence of antimicrobial-resistant bacteria is a matter of concern for public health. The increased rate of bacterial resistance allied with the rather slow development of new antibacterial agents foreshadows a crisis. The actual global antibacterial clinical pipeline is composed of many agents that are modifications of existing classes of antibiotics. ${ }^{1}$ Notwithstanding the efforts done by the scientific community to address the WHO's Global Action Plan on Antimicrobial Resistance, ${ }^{2}$ especially in tackling Gram-negative bacteria, more antibacterials and of narrow scope are necessary. ${ }^{3}$ ESKAPE pathogens (Enterococcus faecium, Staphylococcus aureus, Klebsiella pneumoniae, Acinetobacter baumannii, Pseudomonas aeruginosa, and Enterobacter species) are the leading cause of nosocomial infections worldwide. ${ }^{4,5}$ From these pathogens, E. faecium and S. aureus are Grampositive, and second-generation glycopeptides such as dalbavancin and oritavancin or oxazolidinone linezolid have been described as antibacterial agents against infections by methicillin-resistant $S$. aureus (MRSA) $)^{6,7}$ and vancomycin-resistant enterococci (VRE). ${ }^{5,8}$ Many recent developments have been done towards the treatment of multidrug-resistant Gram-positive pathogens, however, the anticipated fast evolution of resistance makes searches for new antibacterials a timely challenge. ${ }^{9-11}$ S. aureus, E. faecalis, E. faecium and S. epidermidis cause important nosocomial or healthcareassociated infections, a major cause of mortality and morbidity worldwide. ${ }^{12}$ Enterococcus spp. is frequently isolated from the surgical site and bloodstream infections, but rarely found in the respiratory tract..$^{13}$ On the other hand, S. aureus is the primary cause of lower respiratory tract and surgical site infections, and the second leading cause of nosocomial bacteremia, pneumonia and cardiovascular infections. Coagulase-negative staphylococci (CoNS) (especially S. epidermidis) are isolated almost twice as often as $S$. aureus in bloodstream infections. Hospital-acquired listerioses are often-fatal foodborne outbreak infections affecting mainly pregnant and immunocompromised patients, whose sources are difficult to identify. ${ }^{14,15}$

Besides the patient's underlying condition, several factors contribute to the success of these nosocomial pathogens. For instance, the widespread use of broad-spectrum antibiotics promotes the emergence and re-emergence of difficult-to-treat MDR strains, with VRE, MRSA, vancomycin-resistant S. aureus (VRSA) and methicillin-resistant S. epidermidis (MRSE) on the top of the list. ${ }^{16,17}$ Pathogens' persistence on surfaces in the hospital environment, water system, or foreign body devices (such as catheters, implants, vascular grafts, intravenous devices, respiratory equipment, prostheses, etc.) is also a determinant factor for their success. Moreover, the capacity of these pathogens to form biofilms on inert surfaces that are highly resistant to antibiotic treatments and host immune response 18,1920 contributes even more for their persistence and dissemination in the health care setting.

The ability of phenolic Mannich bases to interact with living organisms ${ }^{21}$ has been documented in several reports, biological properties such as antibacterial ${ }^{22}$ and antitumoral, ${ }^{23-28}$ to name a few, have been described. We have previously reported the antibacterial properties of a family of aminoalkylphenols in which the indoline amine counterpart and a para-nitrophenol group were deemed important in conferring antimicrobial properties (Figure 1). Tests against selected Grampositive bacterial strains led to the identification of $1 \mathbf{a}$ as a promising antibacterial agent. ${ }^{29}$ In our follow-up work, ${ }^{30}$ the potency of such derivatives was increased by the introduction of a chlorine substituent in the para-position of the phenyl ring (2a), thus lowering the minimum inhibitory concentration (MIC) to values as low as $1.23 \mu \mathrm{M}$ for multidrug-resistant $S$. aureus and $E$. faecalis. While the influence of diverse substituents in both the phenol and phenyl rings has been evaluated in previous works, the effect of introducing different substituents on the aromatic ring of indoline was not assessed. In the present work, we compile our findings on this missing link to deepen our understanding of the structure-activity relationship of this underexplored class of antimicrobial agents.

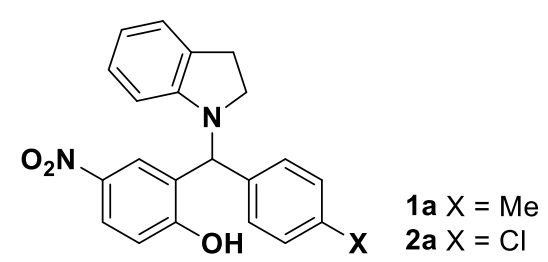

Figure 1. Indoline-derived phenolic Mannich bases previously identified ${ }^{29,30}$ as antibacterials 


\section{Results and discussion}

The compounds have been prepared as previously reported, using the multicomponent Petasis reaction ${ }^{31,32}$ from 5 -nitrosalicylaldehyde, substituted indolines $\mathbf{3}$, and boronic acids $\mathbf{4}$. Some indolines were obtained through the reduction of commercially available indoles with sodium cyanoborohydride or triethylsilane in trifluoroacetic acid. Specifically, sodium cyanoborohydride was used for the reduction of substituted indoles, being replaced by $\mathrm{Et}_{3} \mathrm{SiH}$ and trifluoroacetic acid for deactivated indoles such as in the preparation of $\mathbf{3 d}$ and $\mathbf{3 e}$ (obtained in 96 and $70 \%$ yields, respectively). The condensation of 5-nitrosalicylaldehyde with indolines 3 in 1,2-dichloroethane, followed by reaction of the in situ formed iminium with the suitable boronic acid at $50{ }^{\circ} \mathrm{C}$, provided the desired aminoalkylphenols $\mathbf{1 , 5}$, and $\mathbf{6}$ in good to excellent yields. The procedure was successfully applied to the preparation of aminoalkylphenols derived from three different boronic acids: 4-tolyl (4a), 4-(trifluoromethyl)phenyl (4b) and 2-tolyl (4c) boronic acids providing aminoalkylphenols 1, 5 and 6 respectively. All compounds were isolated by column chromatography, their purity assessed by ${ }^{1} \mathrm{H}$ NMR and their structures confirmed through NMR and HRMS characterization.

Scheme 1. Preparation of aminoalkylphenols studied
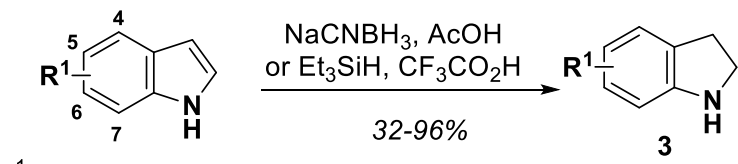

$\mathrm{R}^{1}=5-\mathrm{MeO}, 5-\mathrm{Cl}$

$5-\mathrm{OH}, 5-\mathrm{NO}_{2}, 4-\mathrm{CN}$

$\mathbf{R}^{1}$<smiles></smiles>

3a, $\mathrm{R}^{1}=\mathrm{H}$

3b, $\mathrm{R}^{1}=5-\mathrm{Cl}$

$3 c, R^{1}=5-B r$

$3 d, R^{1}=5-\mathrm{NO}_{2}$

$3 e, R^{1}=4-C N$

3f, $\mathrm{R}^{1}=5-\mathrm{OH}$

$3 g, \mathrm{R}^{1}=5-\mathrm{OCH}_{3}$<smiles></smiles><smiles>O=Cc1cc([N+](=O)[O-])ccc1O</smiles>

4a, $\mathrm{R}^{2}=4-\mathrm{CH}_{3}$

4b, $\mathrm{R}^{2}=4-\mathrm{CF}_{3}$

4c, $\mathrm{R}^{2}=2-\mathrm{CH}_{3}$ 
Table 1. Antimicrobial activity of aminoalkylphenols 1, 2a, 5, and 6 against laboratory-adapted strains. Minimum inhibitory concentrations (MIC) and minimum bactericidal concentrations (MBC) are shown in $\mu \mathrm{M}$.

\begin{tabular}{|c|c|c|c|c|c|c|c|c|c|c|c|c|c|c|}
\hline \multirow[t]{2}{*}{ Compd } & \multicolumn{2}{|c|}{$\begin{array}{c}\text { S. aureus } \\
\text { ATCC } 25923 \\
\text { (MSSA) }\end{array}$} & \multicolumn{2}{|c|}{$\begin{array}{l}\text { S. aureus } \\
\text { ATCC } \\
6538\end{array}$} & \multicolumn{2}{|c|}{$\begin{array}{c}\text { S. aureus } \\
\text { CIP106760 } \\
\text { (MRSA) }\end{array}$} & \multicolumn{2}{|c|}{$\begin{array}{l}\text { E. faecalis } \\
\text { ATCC } \\
29212\end{array}$} & \multicolumn{2}{|c|}{$\begin{array}{c}\text { E. faecalis } \\
\text { ATCC } 51299 \\
\text { (VRE) }\end{array}$} & \multicolumn{2}{|c|}{$\begin{array}{c}\text { S. } \\
\text { epidermidis } \\
\text { ATCC } 12228\end{array}$} & \multicolumn{2}{|c|}{$\begin{array}{l}\text { B. subtilis } \\
\text { ATCC } 6633\end{array}$} \\
\hline & MIC & MBC & MIC & MBC & MIC & MBC & MIC & MBC & MIC & MBC & MIC & MBC & MIC & MB \\
\hline & 1.3 & 7 & .8 & 4 & 2.71 & 2 & 0.8 & 7 & 21.7 & 3 & $-b$ & $-b$ & $-b$ & $-b$ \\
\hline 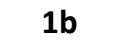 & & & $-b$ & $-b$ & כ) & & & & 30 & & 5.4 & רי & 37. & 151 \\
\hline 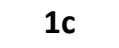 & 0.1 & & $-b$ & $-b$ & 07 & & 07 & & 0.1 & & 43 & 1 & .71 & 9.43 \\
\hline 1 & 2 & & $-b$ & $-b$ & 1.20 & & 20 & 9 & 2.41 & 4 & 8.9 & 7.7 & 18.9 & 37.7 \\
\hline & r & & 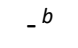 & $-b$ & 2.68 & & 68 & 4 & 5.36 & & 7.8 & & 4.71 & 9.43 \\
\hline & & & $-b$ & $-b$ & & & & & & & & & & $>9.43$ \\
\hline . & .0 & & 0.0 & 0.0 & 10.0 & & 0.0 & & 20.0 & 0 & 1.18 & 4.71 & 1.18 & 4.71 \\
\hline $2 a$ & & & 1.23 & $\gamma$ & 1.23 & & 23 & & 23 & & 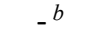 & & $-b$ & $-b$ \\
\hline & & & 1.18 & 2.00 & 1.18 & & 18 & & 18 & & L.18 & $<1.18$ & $<1.18$ & $<1.18$ \\
\hline & 22 & & $-b$ & $-b$ & 1.11 & & 1 & 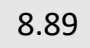 & 45 & 2 & 18 & 6 & .43 & 18.9 \\
\hline & & & .24 & 4.9 & 1.24 & & 24 & & 2.47 & & & 6 & $<1.18$ & 4.71 \\
\hline & & & 11 & 4.45 & & & & & 4.45 & & 1.18 & $<1.18$ & $<1.18$ & $<1.18$ \\
\hline 60 & 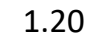 & & 2.41 & 9.64 & 1.20 & & 20 & 9 & 2.41 & 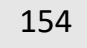 & L.18 & 71 & $<1.18$ & 2.36 \\
\hline & 10.1 & 81.1 & 5.07 & 20.3 & 5.07 & & 5.07 & 81.1 & 10.1 & 162 & 2.36 & 18.9 & 4.71 & 18.9 \\
\hline $\mathrm{CP}^{\mathrm{c}}$ & .40 & $h$ & 1.35 & $-b$ & $<1.50$ & $b$ & 3.07 & $h$ & $<5.83$ & $-b$ & 1.95 & $b$ & 1.95 & $-b$ \\
\hline
\end{tabular}

${ }^{a}$ Previously reported data ${ }^{30} ;{ }^{b}$ not tested; ${ }^{c} \mathrm{CP}-$ positive control (Vancomycin).

Notwithstanding the moderate to good minimum inhibitory concentrations previously determined for $\mathbf{1 a}$, the new 4 -tolyl derivatives $\mathbf{1 b}$-g shown similar to better antibacterial properties. The presence of the nitro group in 5-position of the indolinyl makes it particularly active and compound $\mathbf{1} \mathbf{d}$ resulted in MICs as low as $1.20 \mu \mathrm{M}$. On the other hand, the presence of an oxygen atom in the same 5-position of indolinyl had a detrimental effect on the antibacterial properties. Therefore, compounds $\mathbf{1 f}$ and $\mathbf{1 g}$, decorated with a hydroxy or a methoxy in the 5-positions of indolinyl were generally the least active in the series of 4-tolyl containing aminoalkylphenols 1 . A bioisoster replacement of the methyl group by a trifluoromethyl substituent increased the bacterial growth inhibition as observed for compounds $\mathbf{5 a}$ and $\mathbf{5 d}$. Despite the higher antibacterial effect of $\mathbf{5}$-nitro in $\mathbf{1} \mathbf{d}$ and $4-\mathrm{CF}_{3}$ in $\mathbf{5 a}$ when compared with $\mathbf{1 a}$, the presence of both substituents in $\mathbf{5} \mathbf{d}$ did not confer significantly better antibacterial properties than $\mathbf{5 a}$. Moving the methyl substituent from the 4- to the 2-position had little or no effect on the MICs of S. aureus or E. faecalis strains but inhibit considerably the growth of $S$. epidermidis and $B$. subtilis. Similar levels of growth inhibition were observed for 4-tolyl and 2-tolyl containing aminoalkylphenols 1 and $\mathbf{6}$. Among the indolinyl substituents, the presence of chlorine and nitro in the heterocycle has a clear positive effect in increasing the inhibition properties, as observed for $\mathbf{1} \mathbf{b}$, $\mathbf{1 d}, \mathbf{6 b}$, and $\mathbf{6 d}$. Apart from the VRE strain tested, compounds $\mathbf{5 a}, \mathbf{5 d}$, and $\mathbf{6 b}-\mathbf{d}$ were in general stronger bactericides than compounds 1 .

Considering that phenol compounds may exhibit antioxidant properties, scavenging the excessive amount of free radicals accumulated in the course of microbial infections and that can lead to cellular damage, ${ }^{33,34}$ we wonder if a relation between the electronic character of the indolinyl substituents and such property could be established. Therefore, the antioxidant ability of compounds 1a-1f was investigated using the 2,2-diphenyl-1-picrylhydrazyl (DPPH) method (Figure 2). Indeed, reduced antioxidant activity was observed for highly deactivated indolinyl derivatives $\mathbf{1 d}$ (5-nitro substituted) and 1 e (4-nitrile substituted) in $8 \%$ and $19 \%$, respectively. On the other hand, unsubstituted 1a, halides substituted $\mathbf{1 b}$ and $\mathbf{1 c}$, and hydroxy substituted $\mathbf{1 f}$ indolinyl derivatives showed high scavenging properties, with antioxidant activities higher than $80 \%$. Despite the determined relationship between the electronic properties of the indolinyl substituents and the ability of the studied alkylaminophenols to scavenge free radicals, the antioxidant property does not correlate with the antibacterial effect observed. This corroborates our previous observations, suggesting a mechanism of action that does not involve the scavenging of free radicals. ${ }^{30}$ 


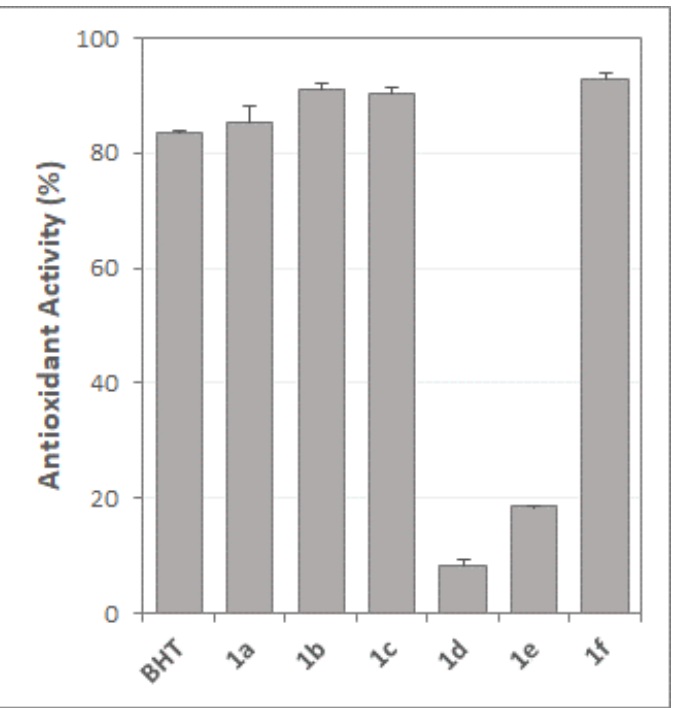

Figure 2. Antioxidant activity of 1a-f by DPPH method. Concentrations of $10 \mu \mathrm{g} / \mathrm{mL}(22-26 \mu \mathrm{M})$ of each compound were subjected to free radical scavenging test. The change in optical density of DPPH was monitored at $517 \mathrm{~nm}$. Butylated hydroxytoluene $(\mathrm{BHT})$ was used as the reference standard. Results are reported as percentage mean values $\pm S D$, based on three independent experiments.

In order to disclose potential applications of the newly synthesized compounds as antibacterial agents, the most active ones, namely $\mathbf{5 a}, \mathbf{5 d}$, and $\mathbf{6 b}-\mathbf{d}$ were considered for further studies regarding their biocompatibility and safety. The same properties were also determined for $1 \mathbf{d}$ for the sake of comparison with compounds $\mathbf{5 d}$ and $\mathbf{6 d}$, as the three molecules contain a nitro group at the 5-position of the indoline moiety, which might confer additional toxicity. ${ }^{35}$

Over the past decades, toxicity testing in pharmaceutical development has been centered on animal models. ${ }^{36,37}$ However, besides expensive and laborious, these models cannot always be translated into the human in vivo responses and, more recently, have reverberated greatly social and ethical dilemmas. ${ }^{38}$ Therefore, the use of alternative models at early phases of drug development is advised. In the present study, we select three distinct approaches to screen the general toxicity of our compounds, namely: i) an invertebrate animal model (Artemia salina brine shrimp); ii) a unicellular fungal model (Saccharomyces cerevisiae), and; iii) two in vitro human cell culture models (a keratinocyte cell line and embryonic lung fibroblast cell line). In contrast to the conventional animal models, these approaches are easy to follow, rapid, cost-effective, and have been increasingly used to screen the general toxicity in a broad spectrum of substances (such as synthetic chemicals, heavy metals, natural products, or engineered nanomaterials), constituting a convenient starting point to prioritize only the best candidates for further screening of vertebrates. ${ }^{38-42}$

Due to their simple anatomy, brief life-cycle, and small size, which allow large-scale screenings, ${ }^{39}$ we started by evaluating the lethality of each compound on the Artemia salina brine shrimp (Figure 3 ). Compared with the previously studied compounds $1 \mathrm{a}$ and $2 \mathrm{a},{ }^{30}$ we were pleased to observe that the newly developed molecules exhibited less toxicity in $\mathbf{A}$. salina than $\mathbf{1 a}$, and were also generally less toxic than $\mathbf{2 a}$. Indeed, with exception of both $\mathbf{1 d}$ and $\mathbf{5 d}$, the remaining compounds promoted a larvae lethality rate below the $15 \%$ observed for $\mathbf{2 a}$, with $\mathbf{6 d}$ displaying a toxicity level similar to that seen for the artificial seawater solution (ca 3\%). The most potent antibacterial agent prepared in this study (5a) showed very little toxicity against $A$. salina (ca. $8 \%$ ), even at a concentration more than one order of magnitude higher than the MICs determined for the several strains. The brine shrimp mortality rates observed after treatment with the 5-nitro indolinyl derivatives $\mathbf{1 d}, \mathbf{5 d}$, and $\mathbf{6} \mathbf{d}$ points out this last compound as being considerably less toxic. The different mortality rates observed for these three compounds indicate that the level of toxicity (even if residual) shall not be attributed to the presence of the second nitro group. 


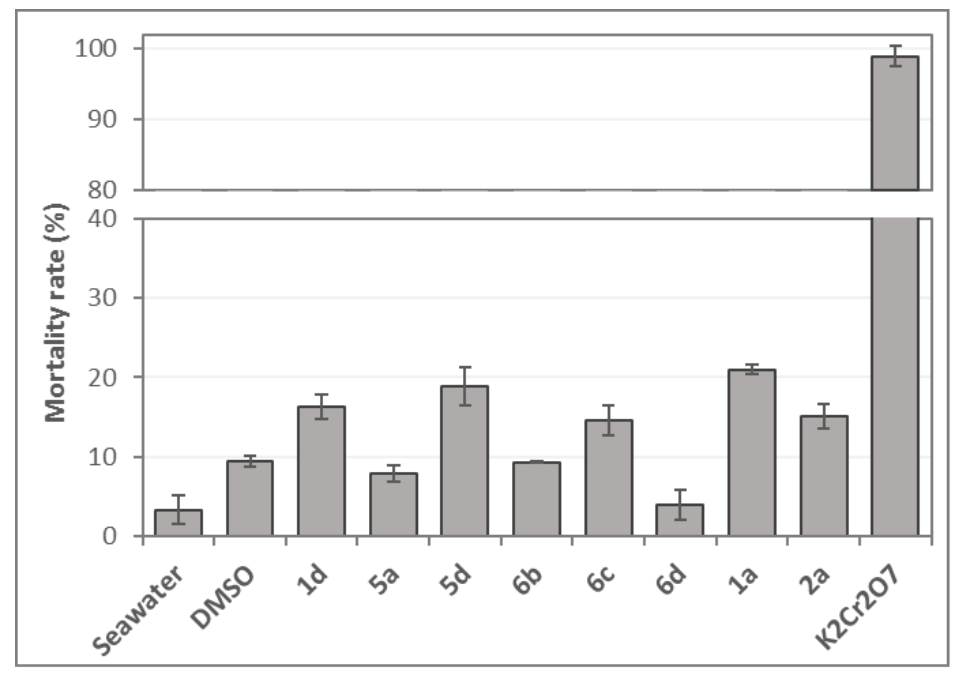

Figure 3. General toxicity of $\mathbf{1 d}, \mathbf{5 a}, \mathbf{5 d}$, and $\mathbf{6 b - \mathbf { d }}$ in the mortality rate of $A$. salina brine shrimp model. Concentrations of $10 \mu \mathrm{g} / \mathrm{mL}(22-28 \mu \mathrm{M})$ of each compound were tested in an artificial seawater solution $(\mathrm{NaCl}$ $3.5 \%$ ) with $1 \%$ of dimethylsulfoxide (DMSO, v/v). Potassium dichromate $\left(\mathrm{K}_{2} \mathrm{Cr}_{2} \mathrm{O}_{7}\right)$ at $10 \mathrm{mg} / \mathrm{mL}$ was used as positive toxic control, while both artificial seawater and DMSO (1\%) were used as negative controls. The previously studied compounds $\mathbf{1}$ a and $\mathbf{2} \mathbf{a}^{30}$ were included for comparative purposes. The number of dead larvae was recorded after 24 hours of exposure and used to calculate the lethal concentration (\%). Results are reported as mean values $\pm S D$, based on three independent experiments.

On the other hand, the yeast $S$. cerevisiae is one of the most popular and widely used eukaryotic models. Besides its rapid growth and ease of replica plating, it can be easily manipulated to evaluate multiple biological effects (inhibition of cellular growth, cytotoxicity and genotoxicity) induced by the drugs considered. ${ }^{40,43}$ According to our results (Figure 4), all tested compounds showed no relevant general toxicity $\left(I C_{50}>100 \mu \mathrm{M}\right)$ when compared to the positive control Nystatin $\left(I C_{50}=3.31 \mu \mathrm{M}\right)$. Overall, the obtained $I_{50}$ values ranged from $121 \mu \mathrm{M}$ for $\mathbf{6 d}$ to $292 \mu \mathrm{M}$ for $\mathbf{5 d}$, with the less active compounds (5d, $\mathbf{1 a}$, and $\mathbf{6 c}$ ) exhibiting, on average, $I C_{50}$ values $\sim 2$-fold higher than the others $(\mathbf{1 d}, \mathbf{5 a}$, $\mathbf{6 b}, \mathbf{6 d}$ and $\mathbf{2 a}$ ). Moreover, the MIC values of $\mathbf{1 d}(1.18-18.9 \mu \mathrm{M}$ ) and $\mathbf{5 a}$ (up to $1.18 \mu \mathrm{M}$ ) are 1-2 orders of magnitude lower (161.8 and $124.3 \mu \mathrm{M}$, respectively) than the $\mathrm{IC}_{50}$ values determined.

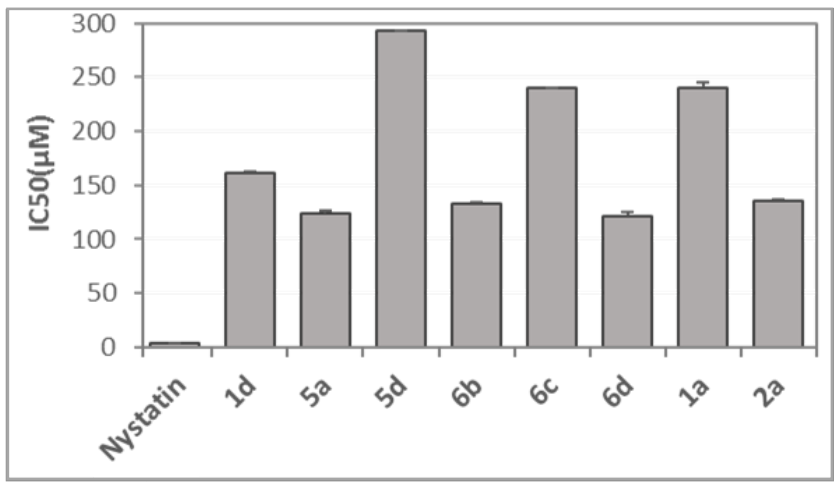

Figure 4. General toxicity of $\mathbf{1 d}, \mathbf{5 a}, \mathbf{5 d}$, and $\mathbf{6 b - \mathbf { d }}$ in Saccharomyces cerevisiae model. The graph depicts the concentration at which each substance induced inhibition of $50 \%\left(\mathrm{IC}_{50}\right)$ in S. cerevisiae viability. Nystatin was used as the positive control. The previously studied compounds $\mathbf{1 a}$ and $\mathbf{2} \mathbf{a}^{30}$ were included for comparative purposes. Results are expressed as mean $\mathrm{IC}_{50}$ values $\pm \mathrm{SD}$, based on three independent experiments.

Despite both organism-based methods being commonly used for initial screening of general toxicity, different toxicity trends were observed for the two species. For instance, among the most active antibacterial compounds tested, $A$. salina was found to be more sensitive to $\mathbf{5 d}$, which was revealed to be the least active compound in S. cerevisiae. On the other hand, S. cerevisiae was mostly sensitive to $\mathbf{6 d}$, the least toxic compound seen for $A$. salina. Considering the different characteristics of each organism, both methods hold limitations that may underline the observed toxicity disparities. For instance, it is known that, in the brine shrimp lethality bioassay, there may be a decrease in the solubility of some chemical substances in the saline medium producing false positives due to the 
toxicity of the solvent itself. ${ }^{39,44}$ Notwithstanding that no ultimate conclusions on the general toxicity of these compounds can be drawn from these protocols, the information collected is valuable in assessing the viability of this family of phenolic Mannich bases in the development of new drugs.

Finally, to unveil some of the potential applications these compounds might have, cytotoxicity was further characterized by using two widely used in vitro cell models of human origin: the HaCat immortalized epidermal keratinocyte line and the MRC-5 embryonic lung fibroblast line. While the former has proved to help evaluate the mechanisms of the cytotoxic and pharmacological action of various agents on the skin, ${ }^{45}$ MRC- 5 cells are a suitable human lung cell model. ${ }^{46}$

Figure 5 shows the viability of HaCat human keratinocytes after $24 \mathrm{~h}$ exposure at $50 \mu \mathrm{M}$ of each compound under evaluation. Overall, the cytotoxic potential observed on the HaCat cells was highly heterogeneous among compounds, with cell viability ranging from $3 \%$ for $\mathbf{6 b}$ (the same magnitude level as the $5 \%$ DMSO positive control) to $94 \%$ for $1 \mathbf{d}$ (similar to that exhibited by non-treated cells). Among 2-tolyl analogs $\mathbf{6}$, compound $\mathbf{6} \mathbf{d}$ was the least cytotoxic to HaCat cells, exhibiting a cytotoxic potential 5.5- and 17.6 -fold lower than $\mathbf{6 c}$ and $\mathbf{6 b}$, respectively. The presence of a halide in the indolinyl moiety is the apparent cause for the increased cytotoxicity to $\mathbf{6 b}$ and $\mathbf{6 c}$ of the 2-tolyl series.

By comparing the 4-tolyl derivative $\mathbf{1} \mathbf{d}$ and its isomer $\mathbf{5} \mathbf{d}$ becomes evident that the cytotoxic disparities observed on HaCat viability may also rely on the influence of the substituent on the phenyl ring (Scheme 1), as the simple exchange of methyl from the 4- to the 2-positions has a prominent increasing effect on the toxicity. Moreover, likewise previously seen in the A. salina model (Figure 3), the additional presence of the $\mathbf{5}$-nitro substituent in $\mathbf{5} \mathbf{d}$ seems to confer higher toxicity in $\mathrm{HaCat}$ cells, when compared to its trifluoromethyl analog $\mathbf{5 a}$ (Figure 5). The most effective antibacterial, $\mathbf{1 d}$, and $\mathbf{5 a}$ showed medium to almost none toxicity for HaCat cells, respectively, with $\mathbf{5 a}$ displaying a cytotoxic potential 0.6-fold lower than that presented by $\mathbf{1 d}$. Notably, this represents a significant improvement when comparing with the previously studied compound $1 a,{ }^{29}$ as $20 \%$ cell viability was observed at a $28 \mu \mathrm{M}$ concentration of that compound. The replacement of the methyl substituent by trifluoromethyl ameliorates the toxicity profile of the compound (i.e. 1a vs 5a) while also greatly increasing its antibacterial properties.

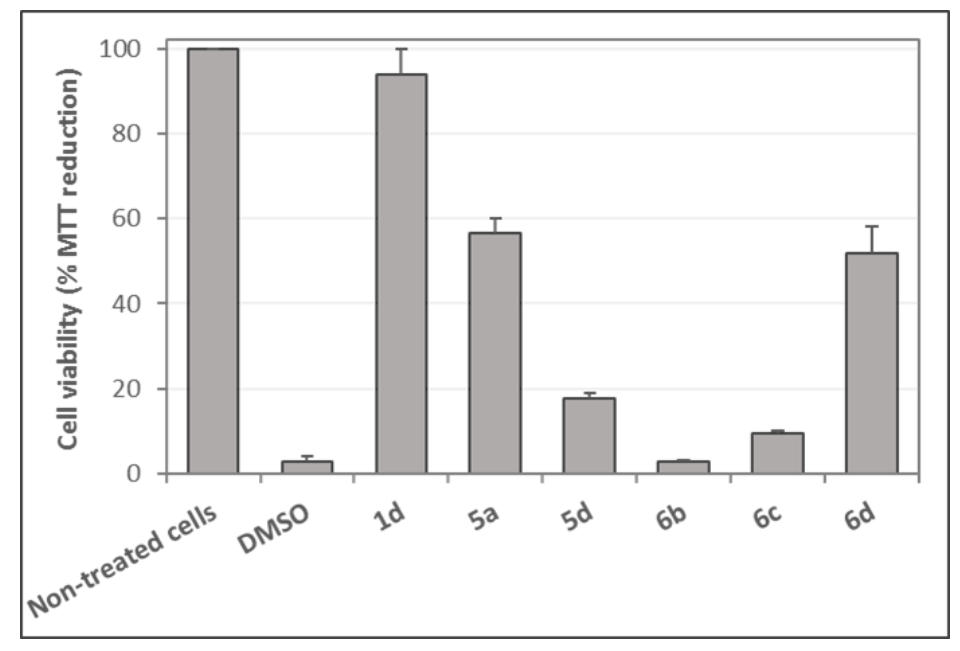

Figure 5. Effect of the synthesized aminoalkylphenols derivatives $\mathbf{1 d}, \mathbf{5 a}, \mathbf{5 d}$, and $\mathbf{6 b}-\mathbf{d}$ on the viability of HaCat human keratinocytes, evaluated by the MTT reduction assay. Cells were treated with each compound at a final concentration of $50 \mu \mathrm{M}$ for $24 \mathrm{~h}$ and then submitted to the MTT colorimetric assay. Dimethylsulfoxide (DMSO $5 \%$ ) was used as the toxic positive control. Results (reported as mean \pm SD) are expressed as percentages relative to non-treated control cells and are based on two independent experiments, each comprising four replicate cultures.

In contrast to that seen for HaCat cells, the cytotoxicity activity of the synthesized aminoalkylphenols derivatives under evaluation was more homogenous and efficacious on MRC-5 cells (Figure 6), with mean $\mathrm{IC}_{50}$ values ranging from $1.7 \mu \mathrm{M}$ for $\mathbf{5 a}$ to $5.8 \mu \mathrm{M}$ for $\mathbf{5 d}$. Surprisingly, $\mathbf{1 d}, \mathbf{5 d}$, and $\mathbf{6 d}$, the three molecules containing a nitro group at the 5 -position of the indoline moiety, exhibited the lowest toxic effect to MRC- 5 cells. Among the 2-tolyl analogs $\mathbf{6}$, compound $\mathbf{6} \mathbf{d}$ was the least toxic, followed by $\mathbf{6 b}$ and $\mathbf{6 c}$. Despite $\mathbf{5 a}$ being found to be the most toxic to MRC-5 cells, it shown an $\mathrm{IC}_{50}$ value only 0.3- 
fold lower than the other most effective antibacterial compound 1d. Generally, the compounds considered for tests on MRC- 5 were observed to have $\mathrm{IC}_{50}$ values higher than the concentration required to inhibit visible bacterial growth. While less cytotoxic than doxorubicin, the similarity between the determined MICs and IC $\mathrm{C}_{50}$ values hamper the clinical use of these compounds in treating lower respiratory infections.

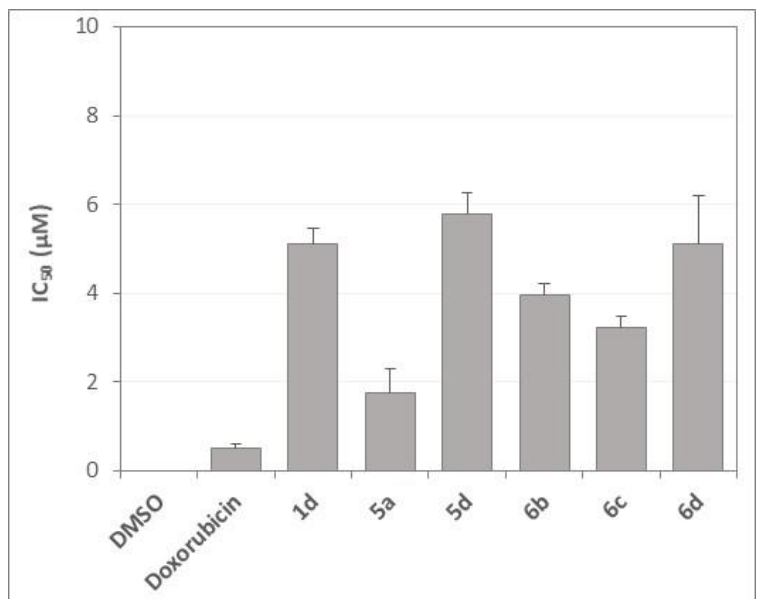

Figure 6. $I C_{50}$ of synthesized aminoalkylphenols derivatives $\mathbf{1 d}, \mathbf{5 a}, \mathbf{5 d}$, and $\mathbf{6 b - \mathbf { d }}$ on MRC-5 human embryonic lung fibroblast cell line. The cell viability was measured by MTT. Doxorubicin was used as a positive toxic control. $I_{50}$ values (reported as mean $\pm S D$ ) are based on 2 independent experiments, each comprising 4 replicate cultures.

Notwithstanding the lack of a possibility to draw clear conclusions on the toxicity of the compounds tested, as no trends could be established with the toxicity models considered, compounds $\mathbf{1} \mathbf{d}$ and $\mathbf{5 a}$, having the strongest antibacterial properties were not particularly toxic against $A$. salina, $S$. cerevisiae, and HaCat. The high and consistent toxicity of the set of compounds tested on MRC-5 can indicate that the class of alkylaminophenols is generally toxic for these cell lines. Nevertheless, motivated by the very good bacterial growth inhibitory properties of $\mathbf{1 d}$ and $\mathbf{5 a}$ (previously performed with reference strains), we extended the antibacterial assays of such molecules against a larger collection of Gram-positive bacterial strains with dissimilar resistance phenotypes, including MRSA, VRE, and multidrug-resistant (MDR) strains. Overall, 40 strains from S. aureus, S. epidermidis, E. faecalis, E. faecium, and Listeria monocytogenes (eight clinical isolates of each species) were tested (Figure 7 and Supplemental Table 1)

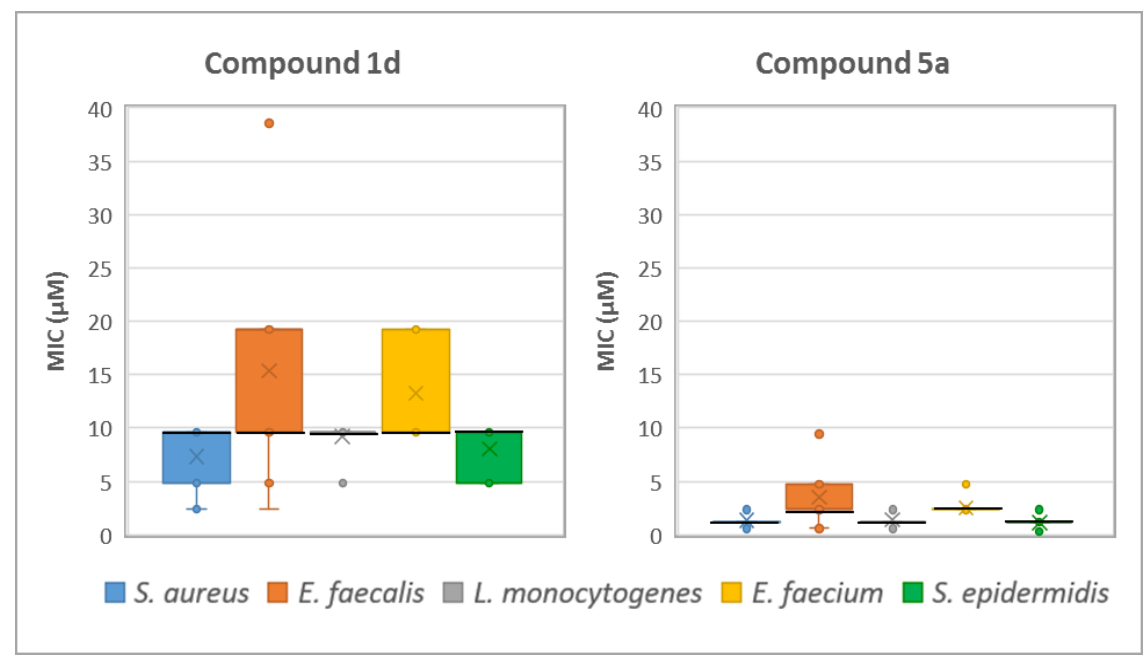

Figure 7. MIC values of compounds $\mathbf{1 d}$ and $\mathbf{5 a}$ for diverse clinical isolates of S. aureus, E. faecalis, L. monocytogenes, E. faecium, and S. epidermidis. Boxplot chart was generated using R statistical software v. 3.4.2 and consists of boxes (median and interquartile range) and whiskers that extend to the most extreme data points that were no more than 1.5 times the interquartile range from the box. Boxes represent the variability of MIC values found among all strains from each species. The horizontal black line marks the median, while the cross $($ " $x$ ") within each box represents the medium MIC value. The lowest and the highest coverage values observed 
are represented by the extremes of the whisker below and above each box, respectively. Outliers are indicated by filled circles.

Similarly, to what was previously observed for the ATCC strains, compound $\mathbf{5 a}$ revealed, in general, a higher and homogeneous antibacterial effect against all clinical isolates than compound 1d. Indeed, lower median MIC values of 4-fold for E. faecium and 8-fold for the remaining species (Figure 7) were determined for $\mathbf{5 a}$, contrasting to the milder effects determined for $\mathbf{1 d}$. The median MIC values displayed by compound 5a ranged from $1.18 \mu \mathrm{M}$ for S. aureus, S. epidermidis and L. monocytogenes to $2.36 \mu \mathrm{M}$ for both Enterococcus species, while compound 1d exhibited median MICs of $9.64 \mu \mathrm{M}$ for all species' clinical isolates except for E. faecalis, for which the median MIC was $19.27 \mu \mathrm{M}$. Moreover, whereas compound $\mathbf{5 a}$ exhibited comparable MIC values between the ATCC adapted strains and clinical isolates of both Staphylococcus species and E. faecalis, compound $\mathbf{1 d}$ revealed median MIC values 2-fold higher for the $S$. epidermidis ATCC adapted strains, but at least an 8-fold lower difference for $E$. faecalis clinical isolates. Such intra-species discrepancies observed for compound $\mathbf{1 d}$ may be due to: $i)$ the dissimilar genetic background of the clinical isolates, ii) to the low number of ATCC strains tested, and iii) to the extensive in vitro passaging of ATCC strains.

\section{Conclusions}

In summary, this work presents the preparation of new phenol Mannich bases, easily prepared from the multicomponent Petasis reaction, the assessment of their antibacterial properties, as well as their toxicity in vivo (on A. salina and S. cerevisiae) and in vitro (on keratinocyte and embryonic lung fibroblast cell lines).

This work corroborates the previous observations that this class of compounds is generally effective against multi-resistant Gram-positive bacteria. The introduction of different substituents in the indoline moiety contributed to a significant change in the antibacterial properties of previously reported analogs. The presence of an additional nitro substituent at the 5 -indolinyl position conferred additional antibacterial activity and decreased the antioxidant activity. Despite the noticeable effect of the indoline's substituents on the antioxidant activity, a lack of correlation between the antibacterial properties of aminoalkylphenols and such property was also corroborated.

Apart from the increased toxic effect observed by $\mathbf{5 d}$ on HaCat cell lines, the 5-nitroindolinyl derivatives did not show increased toxicity when compared with other analogs. Moreover, 5nitroindolinyl derivative 1d was determined to have increased antibacterial properties while not significantly increasing its toxicity to the eukaryotic systems considered. The installation of a trifluoromethyl substituent in the para-position of the aromatic ring also led to the improvement of the antibacterial properties. The 5-nitroindolinyl and trifluoromethylated derivatives (1d and $\mathbf{5 a}$, respectively) are efficient growth inhibitors of the five Gram-positive bacterial strains tested ( $S$. aureus, S. epidermidis, E. faecalis, E. faecium, and L. monocytogenes). In particular, the antibacterial efficacy of compound $\mathbf{5 a}$ translates into MIC's lower than $5 \mu \mathrm{M}$ for tested reference strains and clinical isolates. While these compounds demonstrated trivial toxicity on the in vivo models tested, they exerted a toxic effect on normal human embryonic lung fibroblast cells indicating that the in vivo use of the compounds may be limited. Nevertheless, given the excellent antibacterial properties of these compounds and the urgent need to find new chemical entities toxic to pathogenic microorganisms, efforts are being carried out to find a suitable system for their delivery on living organisms, understand their mechanism of action, and evaluate their toxicity in other cell lines presents an opportunity for further research.

\section{Materials and methods}

\subsection{Synthesis}

\subsubsection{General Remarks}

All reagents were obtained from Sigma-Aldrich or $\mathrm{TCl}$ and were used without further purification. Reactions were performed under argon atmosphere and monitored by thin-layer chromatography carried out on precoated (Merck TLC silica gel 60 F254) aluminum plates by using UV light as a visualizing agent and cerium molybdate solution or ninhydrin as developing agents. Flash column 
chromatography was performed on silica gel 60 (Merck, 0.040-0.063 mm). NMR spectra were recorded with Varian Mercury $300 \mathrm{MHz}$ or JEOL ECZR 500 instruments using $\mathrm{CDCl}_{3}$, DMSO- $\mathrm{d}_{6}$, or methanol- $\mathrm{d}_{4}$ as solvents and calibrated using tetramethylsilane as an internal standard. Chemical shifts $(\delta)$ are reported in ppm referenced to the non-deuterated residual peak $\left(\delta 7.26\right.$ for $\mathrm{CDCl}_{3}, \delta 2.50$ for DMSO- $\mathrm{d}_{6}$ and $\delta 3.31$ for $\left.\mathrm{MeOH}-\mathrm{d}_{4}\right)$ or TMS peak $(\delta 0.00)$ for ${ }^{1} \mathrm{H}$ NMR. The same approach was used

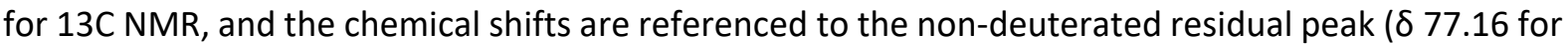
$\mathrm{CDCl}_{3}, \delta 39.50$ for DMSO- $\mathrm{d}_{6}$, and $\delta 49.00$ for $\left.\mathrm{MeOH}-\mathrm{d}_{4}\right)$. The following abbreviations were used to describe peak splitting patterns: $\mathrm{s}=$ singlet, $\mathrm{d}=$ doublet, $\mathrm{t}=$ triplet, $\mathrm{m}=$ multiplet. Coupling constants, $J$, were reported in hertz. High-resolution mass spectra were recorded on a Waters ESI-TOF MS spectrometer. All compounds tested for antibacterial activity were established to be $>95 \%$ pure upon NMR analysis.

\subsubsection{Preparation of indolines 3}

All indolines, except indoline (3a) and 5-bromoindoline (3c) which were obtained commercially, were synthesized by reducing commercially available indoles with sodium cyanoborohydride (Method $A$ ) or triethylsilane (Method B).

Method A: Acetic acid ( $10 \mathrm{~mL}$ ) was added to a flask charged with sodium cyanoborohydride ( $3 \mathrm{mmol}$, 3 equiv.) and indole ( $1 \mathrm{mmol}, 1$ equiv.) at $0{ }^{\circ} \mathrm{C}$, under argon. The partially frozen mixture was stirred fast for 5 minutes and moved to ambient temperature. The reaction was stirred until TLC indicated completion of the reaction. Acetic acid was evaporated under reduced pressure and the residue was dissolved in $15 \mathrm{~mL}$ of DCM. The resulting mixture was washed with $15 \mathrm{~mL}$ of saturated aqueous $\mathrm{Na}_{2} \mathrm{CO}_{3}$ and the aqueous layer from the washing was extracted with $3 \times 5 \mathrm{~mL}$ of DCM. Organic extracts were combined, dried over $\mathrm{MgSO}_{4}$, filtered, and evaporated under reduced pressure. The residue was purified by column chromatography to obtain the desired indoline.

Method B: Triethylsilane ( $2.6 \mathrm{mmol}, 2.6$ equiv.) was added dropwise to a stirred suspension of indole (1 mmol, 1 equiv.) in $1.5 \mathrm{~mL}$ of trifluoroacetic acid at ambient temperature, under argon. The reaction was heated to $50^{\circ} \mathrm{C}$ and stirred until TLC indicated completion of the reaction. Trifluoroacetic acid was evaporated under reduced pressure and the residue was diluted with $5 \mathrm{~mL}$ of DCM. The resulting mixture was washed with $5 \mathrm{~mL}$ of saturated aqueous $\mathrm{NaHCO}_{3}$ and the aqueous layer from the washing was extracted with $2 \times 5 \mathrm{~mL}$ of DCM. Organic extracts were combined, dried over $\mathrm{Na}_{2} \mathrm{SO}_{4}$, filtered, and evaporated under reduced pressure. The residue was purified by column chromatography to obtain the desired indoline.

5-chloroindoline (3b): Method A provided the titled compound in $89 \%$ yield after $3 \mathrm{~h}$ reaction time, with similar spectral data to previously reported..$^{47} \mathrm{H} \mathrm{NMR}\left(300 \mathrm{MHz}, \mathrm{CDCl}_{3}\right) \delta 6.99(\mathrm{~d}, \mathrm{~J}=1.8 \mathrm{~Hz}, 1 \mathrm{H})$, $6.88(\mathrm{dd}, \mathrm{J}=2.3,8.2 \mathrm{~Hz}, 1 \mathrm{H}), 6.46(\mathrm{~d}, \mathrm{~J}=8.2 \mathrm{~Hz}, 1 \mathrm{H}), 3.50(\mathrm{t}, \mathrm{J}=8.2 \mathrm{~Hz}, 2 \mathrm{H}), 2.94(\mathrm{t}, \mathrm{J}=8.5 \mathrm{~Hz}, 2 \mathrm{H})$.

5 -nitroindoline (3d): Method B provided the titled compound in $96 \%$ yield after 30 min reaction time, with similar spectral data to previously reported. ${ }^{481} \mathrm{H} \mathrm{NMR}\left(300 \mathrm{MHz}, \mathrm{CDCl}_{3}\right) \delta 7.99$ (dd, J=2.3, $8.8 \mathrm{~Hz}$, $1 \mathrm{H}), 7.94(\mathrm{~s}, 1 \mathrm{H}), 6.47(\mathrm{~d}, \mathrm{~J}=8.8 \mathrm{~Hz}, 1 \mathrm{H}), 4.53$ (br. s, 1H), $3.76(\mathrm{t}, \mathrm{J}=8.8 \mathrm{~Hz}, 2 \mathrm{H}), 3.12(\mathrm{t}, \mathrm{J}=8.8 \mathrm{~Hz}, 2 \mathrm{H})$.

Indoline-4-carbonitrile (3e): Method B provided the titled compound in 70\% yield after 30 min reaction time, with similar spectral data to previously reported. ${ }^{49}{ }^{1} \mathrm{H}$ NMR $(500 \mathrm{MHz}$, DMSO-d $) \delta 7.05(\mathrm{t}, \mathrm{J}=7.7$ $\mathrm{Hz}, 1 \mathrm{H}), 6.83$ (d, J=7.4 Hz, 1H), 6.72 (d, J=8.0 Hz, 1H), 6.02 (br. s, 1H), 3.51 (td, J=8.6, $1.1 \mathrm{~Hz}, 2 \mathrm{H}$ ), 3.08 $(\mathrm{t}, \mathrm{J}=8.6 \mathrm{~Hz}, 2 \mathrm{H})$.

Indolin-5-ol (3f): Sodium cyanoborohydride ( $189 \mathrm{mg}, 3 \mathrm{mmol}, 3$ equiv.) was added in small portions to a stirred solution of $1 \mathrm{H}$-indol-5-ol (133 mg, $1 \mathrm{mmol}, 1$ equiv.) in $10 \mathrm{~mL}$ of acetic acid at ambient temperature, under argon. The reaction was stirred for 80 minutes and the acetic acid was evaporated under reduced pressure. The residue was diluted with $2.5 \mathrm{~mL}$ of hexane, $2.5 \mathrm{~mL}$ of DCM, and finally basified with $3 \mathrm{~mL}$ of triethylamine. Solvents and the remaining triethylamine were evaporated under reduced pressure and the residue was suspended in $10 \mathrm{~mL}$ of diethyl ether. The suspension was filtered through a celite pad and the pad was washed with $2 \times 10 \mathrm{~mL}$ of $\mathrm{Et}_{2} \mathrm{O}$. Filtrates were combined, dried over $\mathrm{Na}_{2} \mathrm{SO}_{4}$, filtered, and evaporated under reduced pressure. The residue was purified by column chromatography to obtain the title compound with $32 \%$ yield, with similar spectral data to previously reported. ${ }^{50}{ }^{1} \mathrm{H}$ NMR $\left(300 \mathrm{MHz}, \mathrm{CDCl}_{3}\right) \delta 6.59(\mathrm{~s}, 1 \mathrm{H}), 6.50(\mathrm{~d}, \mathrm{~J}=8.2 \mathrm{~Hz}, 1 \mathrm{H}), 6.43$ (dd, J=2.3, $8.2 \mathrm{~Hz}, 1 \mathrm{H}$ ), 4.53 (br. s, 3H), 3.46 (t, J=8.2 Hz, 2H), 2.92 (t, J=8.5 Hz, 2H). 
5-methoxyindoline (3g): Method A provided the titled compound in $82 \%$ yield after $1 \mathrm{~h}$ reaction time, with similar spectral data to previously reported. ${ }^{51}{ }^{1} \mathrm{H} \mathrm{NMR}\left(300 \mathrm{MHz}, \mathrm{CDCl}_{3}\right) \delta 6.69(\mathrm{~s}, 1 \mathrm{H}), 6.52-6.52$ (m, 2H), $3.67(\mathrm{~s}, 3 \mathrm{H}), 3.46(\mathrm{t}, \mathrm{J}=8.2 \mathrm{~Hz}, 2 \mathrm{H}), 3.40$ (br. s, $1 \mathrm{H}), 2.93(\mathrm{t}, \mathrm{J}=8.5 \mathrm{~Hz}, 2 \mathrm{H})$.

\subsubsection{Preparation of Phenol Mannich bases $\mathbf{1 , 5}$ and $\mathbf{6}$}

General procedure: Aldehyde ( $0.5 \mathrm{mmol}, 1$ equiv.) and arylboronic acid ( $0.5 \mathrm{mmol}, 1$ equiv.) were dissolved in $5 \mathrm{~mL}$ of DCE and heated to $50^{\circ} \mathrm{C}$. After stirring for 5 minutes, indoline ( $0.5 \mathrm{mmol}, 1$ equiv.) was added in one portion. Stirring was continued until TLC indicated completion of the reaction. The solvent was evaporated under reduced pressure and the residue was purified by column chromatography to obtain the desired aminoalkylphenol.

2-((5-Chloroindolin-1-yl)(p-tolyl)methyl)-4-nitrophenol (1) $)$ : Obtained in $83 \%$ yield as an off-white solid. ${ }^{1} \mathrm{H}$ NMR $\left(300 \mathrm{MHz}, \mathrm{CDCl}_{3}\right) \delta 11.39$ (br. s, $\left.1 \mathrm{H}\right), 8.10$ (dd, J=2.6, $\left.9.1 \mathrm{~Hz}, 1 \mathrm{H}\right), 7.95$ (d, J=2.9 Hz, 1H), $7.28(\mathrm{~d}, \mathrm{~J}=8.2 \mathrm{~Hz}, 2 \mathrm{H}), 7.12-7.18(\mathrm{~m}, 3 \mathrm{H}), 6.95(\mathrm{~d}, \mathrm{~J}=8.8 \mathrm{~Hz}, 2 \mathrm{H}), 6.38(\mathrm{~d}, \mathrm{~J}=8.2 \mathrm{~Hz}, 1 \mathrm{H}), 5.29(\mathrm{~s}, 1 \mathrm{H}), 3.20-$ $3.27(\mathrm{~m}, 1 \mathrm{H}), 3.09(\mathrm{q}, \mathrm{J}=9.6 \mathrm{~Hz}, 1 \mathrm{H}), 2.84-3.00(\mathrm{~m}, 2 \mathrm{H}), 2.34(\mathrm{~s}, 3 \mathrm{H}) .{ }^{13} \mathrm{C} \mathrm{NMR}\left(75 \mathrm{MHz}, \mathrm{CDCl}_{3}\right) \delta 162.39$, $148.82,140.83,138.89,134.63,134.33,129.87,128.56,127.27,126.48,125.17,124.73,117.61$, 113.00, 70.06, 53.57, 28.24, 21.11. HRMS (ESI/TOF): $\mathrm{m} / \mathrm{z}$ calcd for $\mathrm{C}_{22} \mathrm{H}_{19} \mathrm{ClN}_{2} \mathrm{O}_{3}{ }^{+}[\mathrm{M}]^{+}, 394.1079$; found 394.1061.

2-((5-Bromoindolin-1-yl)(p-tolyl)methyl)-4-nitrophenol (1c): Obtained in $85 \%$ yield as a pale yellow solid. ${ }^{1} \mathrm{H}$ NMR $\left(300 \mathrm{MHz}, \mathrm{CDCl}_{3}\right) \delta 11.30$ (br. s, $\left.1 \mathrm{H}\right), 8.10$ (dd, J=2.9, $\left.8.8 \mathrm{~Hz}, 1 \mathrm{H}\right), 7.95$ (d, J=2.9 Hz, $1 \mathrm{H}$ ), 7.26-7.30 (m, 3H), 7.16-7.18 (m, 2H), 7.10 (dd, J=2.1, 8.5 Hz, 1H), $6.96(\mathrm{~d}, \mathrm{~J}=8.8 \mathrm{~Hz}, 1 \mathrm{H}), 6.34(\mathrm{~d}, \mathrm{~J}=8.8$ $\mathrm{Hz}, 1 \mathrm{H}), 5.30(\mathrm{~s}, 1 \mathrm{H}), 3.20-3.27(\mathrm{~m}, 1 \mathrm{H}), 3.05-3.14(\mathrm{~m}, 1 \mathrm{H}), 2.85-3.01(\mathrm{~m}, 2 \mathrm{H}), 2.34(\mathrm{~s}, 3 \mathrm{H}) .{ }^{13} \mathrm{C}$ NMR $(75$ $\left.\mathrm{MHz}, \mathrm{CDCl}_{3}\right) \delta 162.35,149.31,140.86,138.92,134.72,134.56,130.20,129.88,128.58,128.00,126.44$, $125.19,124.73,117.62,114.62,113.49,69.88,53.47,28.18,21.12$. HRMS (ESI/TOF): $\mathrm{m} / \mathrm{z}$ calcd for $\mathrm{C}_{22} \mathrm{H}_{19} \mathrm{BrN}_{2} \mathrm{O}_{3}^{+}[\mathrm{M}]^{+}, 438.0574$; found 438.0571 .

4-Nitro-2-((5-nitroindolin-1-yl)(p-tolyl)methyl)phenol (1d): Obtained in $85 \%$ yield as an orange red solid. ${ }^{1} \mathrm{H}$ NMR $\left(500 \mathrm{MHz}, \mathrm{CDCl}_{3}\right) \delta 8.17(\mathrm{~s}, 1 \mathrm{H}), 8.13(\mathrm{dd}, \mathrm{J}=8.9,2.6 \mathrm{~Hz}, 1 \mathrm{H}), 7.98(\mathrm{~d}, \mathrm{~J}=2.9 \mathrm{~Hz}, 1 \mathrm{H})$, 7.91-7.94 (m, 2H), $7.18(\mathrm{q}, \mathrm{J}=8.6 \mathrm{~Hz}, 4 \mathrm{H}), 7.03(\mathrm{~d}, \mathrm{~J}=9.2 \mathrm{~Hz}, 1 \mathrm{H}), 6.25(\mathrm{~d}, \mathrm{~J}=8.6 \mathrm{~Hz}, 1 \mathrm{H}), 6.02(\mathrm{~s}, 1 \mathrm{H})$, 3.44-3.54 (m, 2H), $3.10(\mathrm{t}, \mathrm{J}=8.6 \mathrm{~Hz}, 2 \mathrm{H}), 2.36(\mathrm{~s}, 3 \mathrm{H}) .{ }^{13} \mathrm{C} \mathrm{NMR}\left(126 \mathrm{MHz}, \mathrm{CDCl}_{3}\right) \delta$ 160.38, 156.40, $141.22,138.88,138.53,133.55,130.90,129.84,128.07,126.58,126.42,125.51,125.15,120.80$, $116.65,106.05,60.25,51.24,26.96,21.11$. HRMS (ESI/TOF): $\mathrm{m} / \mathrm{z}$ calcd for $\mathrm{C}_{22} \mathrm{H}_{19} \mathrm{~N}_{3} \mathrm{O}_{5}{ }^{+}[\mathrm{M}]^{+}, 405.1319$; found 405.1302 .

1-((2-Hydroxy-5-nitrophenyl)(p-tolyl)methyl)indoline-4-carbonitrile (1e): Obtained in $39 \%$ yield as a pale yellow solid. ${ }^{1} \mathrm{H}$ NMR $\left(300 \mathrm{MHz}, \mathrm{CDCl}_{3}\right) \delta 10.37$ (br. s, $\left.1 \mathrm{H}\right), 8.12$ (dd, J=2.9, $\left.8.8 \mathrm{~Hz}, 1 \mathrm{H}\right), 7.98(\mathrm{~d}$, $\mathrm{J}=2.9 \mathrm{~Hz}, 1 \mathrm{H}), 7.27(\mathrm{~d}, \mathrm{~J}=7.6 \mathrm{~Hz}, 2 \mathrm{H}), 7.19(\mathrm{~d}, \mathrm{~J}=8.2 \mathrm{~Hz}, 2 \mathrm{H}), 7.05-7.14(\mathrm{~m}, 2 \mathrm{H}), 6.98(\mathrm{~d}, \mathrm{~J}=8.8 \mathrm{~Hz}, 1 \mathrm{H})$, $6.62(\mathrm{dd}, \mathrm{J}=1.8,7.0 \mathrm{~Hz}, 1 \mathrm{H}), 5.41(\mathrm{~s}, 1 \mathrm{H}), 3.31-3.39(\mathrm{~m}, 1 \mathrm{H}), 3.09-3.27(\mathrm{~m}, 3 \mathrm{H}), 2.35(\mathrm{~s}, 3 \mathrm{H}) .{ }^{13} \mathrm{C} \mathrm{NMR}(75$ $\left.\mathrm{MHz}, \mathrm{CDCl}_{3}\right) \delta 161.73,151.07,141.10,139.11,136.66,134.11,130.01,128.58,128.52,126.29,125.33$, $124.81,124.32,117.60,117.13,115.42,109.14,68.59,52.81,27.93,21.13$. HRMS (ESI/TOF): $\mathrm{m} / \mathrm{z}$ calcd for $\mathrm{C}_{23} \mathrm{H}_{19} \mathrm{~N}_{3} \mathrm{O}_{3}{ }^{+}[\mathrm{M}]^{+}, 385.1421$; found 385.1425 .

1-((2-Hydroxy-5-nitrophenyl)(p-tolyl)methyl)indolin-5-ol (1f): Obtained in 20\% yield as an orange solid. ${ }^{1} \mathrm{H} \mathrm{NMR}\left(300 \mathrm{MHz}, \mathrm{CDCl}_{3}\right) \delta 8.09$ (dd, J=2.9, $\left.9.4 \mathrm{~Hz}, 1 \mathrm{H}\right), 7.93(\mathrm{~d}, \mathrm{~J}=2.9 \mathrm{~Hz}, 1 \mathrm{H}), 7.29(\mathrm{~d}, \mathrm{~J}=8.2 \mathrm{~Hz}, 2 \mathrm{H})$, $7.15(\mathrm{~d}, \mathrm{~J}=8.2 \mathrm{~Hz}, 2 \mathrm{H}), 6.94(\mathrm{~d}, \mathrm{~J}=9.4 \mathrm{~Hz}, 1 \mathrm{H}), 6.69$ (d, J=2.3 Hz, 1H), 6.45 (dd, J=2.9, $8.8 \mathrm{~Hz}, 1 \mathrm{H}), 6.29$ $6.36(\mathrm{~m}, 1 \mathrm{H}), 5.17(\mathrm{~s}, 1 \mathrm{H}), 3.16-3.23(\mathrm{~m}, 1 \mathrm{H}), 2.96-3.05(\mathrm{~m}, 1 \mathrm{H}), 2.79-2.94(\mathrm{~m}, 2 \mathrm{H}), 2.33(\mathrm{~s}, 3 \mathrm{H}) .{ }^{13} \mathrm{C} \mathrm{NMR}$ $\left(75 \mathrm{MHz}, \mathrm{CDCl}_{3}\right) \delta 163.04,151.63,143.67,140.57,138.73,135.29,134.48,129.78,128.53,126.91$, $125.06,124.66,117.59,113.58,113.35,112.60,71.63,53.95,28.64,21.12$. HRMS (ESI/TOF): $\mathrm{m} / \mathrm{z}$ calcd for $\mathrm{C}_{22} \mathrm{H}_{19} \mathrm{~N}_{2} \mathrm{O}_{4}^{-}[\mathrm{M}-\mathrm{H}]^{-}, 375.1350$; found 375.1343 .

2-((5-Methoxyindolin-1-yl)(p-tolyl)methyl)-4-nitrophenol (19): Obtained in $68 \%$ yield as a pale yellow solid. ${ }^{1} \mathrm{H}$ NMR $\left(300 \mathrm{MHz}, \mathrm{CDCl}_{3}\right) \delta 8.01(\mathrm{dd}, \mathrm{J}=2.3,8.8 \mathrm{~Hz}, 1 \mathrm{H}), 7.87(\mathrm{~d}, \mathrm{~J}=2.9 \mathrm{~Hz}, 1 \mathrm{H}), 7.22(\mathrm{~d}, \mathrm{~J}=8.2 \mathrm{~Hz}$, $2 \mathrm{H}), 7.08(\mathrm{~d}, \mathrm{~J}=7.6 \mathrm{~Hz}, 2 \mathrm{H}), 6.87(\mathrm{~d}, \mathrm{~J}=8.8 \mathrm{~Hz}, 1 \mathrm{H}), 6.69$ (d, J=2.3 Hz, 1H), 6.46 (dd, J=2.9, $8.8 \mathrm{~Hz}, 1 \mathrm{H})$, $6.32(\mathrm{~d}, \mathrm{~J}=8.8 \mathrm{~Hz}, 1 \mathrm{H}), 5.12(\mathrm{~s}, 1 \mathrm{H}), 3.65(\mathrm{~s}, 3 \mathrm{H}), 3.10-3.16(\mathrm{~m}, 1 \mathrm{H}), 2.84-2.96(\mathrm{~m}, 1 \mathrm{H}), 2.75-2.81(\mathrm{~m}, 2 \mathrm{H})$, 2.26 (s, 3H). ${ }^{13} \mathrm{C} \mathrm{NMR}\left(75 \mathrm{MHz}, \mathrm{CDCl}_{3}\right) \delta 163.03,155.85,143.71,140.61,138.70,135.34,134.26$, 129.79, 128.53, 126.93, 125.04, 124.65, 117.59, 113.19, 111.86, 111.68, 71.61, 55.65, 53.99, 28.73, 21.12. HRMS (ESI/TOF): $\mathrm{m} / \mathrm{z}$ calcd for $\mathrm{C}_{22} \mathrm{H}_{19} \mathrm{~N}_{2} \mathrm{O}_{3}{ }^{+}[\mathrm{M}]^{+}, 390,1574$; found 390.1574 .

2-(Indolin-1-yl(4-(trifluoromethyl)phenyl)methyl)-4-nitrophenol (5a): Obtained in $80 \%$ yield as a pale yellow solid. ${ }^{1} \mathrm{H}$ NMR $\left(300 \mathrm{MHz}, \mathrm{CDCl}_{3}\right) \delta 8.13(\mathrm{dd}, \mathrm{J}=2.6,9.1 \mathrm{~Hz}, 1 \mathrm{H}), 7.95(\mathrm{~d}, \mathrm{~J}=2.9 \mathrm{~Hz}, 1 \mathrm{H}), 7.56-7.66$ $(\mathrm{m}, 4 \mathrm{H}), 7.20(\mathrm{~d}, \mathrm{~J}=7.0 \mathrm{~Hz}, 1 \mathrm{H}), 6.92-7.05(\mathrm{~m}, 3 \mathrm{H}), 6.49(\mathrm{~d}, \mathrm{~J}=7.6 \mathrm{~Hz}, 1 \mathrm{H}), 5.42(\mathrm{~s}, 1 \mathrm{H}), 3.19-3.26(\mathrm{~m}, 1 \mathrm{H})$, 
2.93-3.08 (m, 3H). ${ }^{13} \mathrm{C} \mathrm{NMR}\left(75 \mathrm{MHz}, \mathrm{CDCl}_{3}\right) \delta 162.46,149.89,141.95,140.95,132.23,131.27,129.07$, $127.63,126.29,126.24,126.20,126.14,125.94,125.49,125.11,124.55,122.70,117.91,112.24,70.07$, 53.79, 28.47. HRMS (ESI/TOF): $\mathrm{m} / \mathrm{z}$ calcd for $\mathrm{C}_{22} \mathrm{H}_{18} \mathrm{~F}_{3} \mathrm{~N}_{2} \mathrm{O}_{3}{ }^{+}[\mathrm{M}+\mathrm{H}]^{+}, 415.1264$; found 415.1286 .

4-Nitro-2-((5-nitroindolin-1-yl)(4-(trifluoromethyl)phenyl)methyl)phenol (5d): Obtained in 77\% yield as an orange red solid. ${ }^{1} \mathrm{H} \mathrm{NMR}\left(300 \mathrm{MHz}, \mathrm{CDCl}_{3}\right) \delta 8.11(\mathrm{dd}, \mathrm{J}=2.6,9.1 \mathrm{~Hz}, 1 \mathrm{H}), 7.89-7.91(\mathrm{~m}, 3 \mathrm{H}), 7.60$ (d, J=8.2 Hz, 2H), $7.37(\mathrm{~d}, \mathrm{~J}=8.2 \mathrm{~Hz}, 2 \mathrm{H}), 6.94(\mathrm{~d}, \mathrm{~J}=8.8 \mathrm{~Hz}, 1 \mathrm{H}), 6.21(\mathrm{~d}, \mathrm{~J}=9.4 \mathrm{~Hz}, 1 \mathrm{H}), 6.01(\mathrm{~s}, 1 \mathrm{H}), 3.36-$ $3.43(\mathrm{~m}, 2 \mathrm{H}), 3.07(\mathrm{t}, \mathrm{J}=8.8 \mathrm{~Hz}, 2 \mathrm{H}) .{ }^{13} \mathrm{C}$ NMR $\left(75 \mathrm{MHz}, \mathrm{CDCl}_{3}\right) \delta 159.96,156.12,141.45,141.13,139.18$, 130.61, 128.46, 126.40, 126.15, 125.89, 125.77, 125.17, 120.93, 116.65, 105.75, 59.44, 51.12, 27.04. HRMS (ESI/TOF): $\mathrm{m} / \mathrm{z}$ calcd for $\mathrm{C}_{22} \mathrm{H}_{15} \mathrm{~F}_{3} \mathrm{~N}_{3} \mathrm{O}_{5}{ }^{-}[\mathrm{M}-\mathrm{H}]^{-}$, 458.0969; found 458.0962 .

2-((5-Chloroindolin-1-yl)(o-tolyl)methyl)-4-nitrophenol (6b): Obtained in $62 \%$ yield as a pale yellow solid. ${ }^{1} \mathrm{H} \mathrm{NMR}\left(300 \mathrm{MHz}, \mathrm{CDCl}_{3}\right) \delta 8.11$ (dd, J=2.6, $\left.9.1 \mathrm{~Hz}, 1 \mathrm{H}\right), 7.87$ (d, J=2.9 Hz, $\left.1 \mathrm{H}\right), 7.35$ (d, J=7.0 Hz, $1 \mathrm{H})$, 7.13-7.23 (m, 4H), 6.93-6.98 (m, 2H), $6.27(\mathrm{~d}, \mathrm{~J}=8.2 \mathrm{~Hz}, 1 \mathrm{H}), 5.69(\mathrm{~s}, 1 \mathrm{H}), 3.23-3.28(\mathrm{~m}, 1 \mathrm{H}), 2.92-$ $3.10(\mathrm{~m}, 3 \mathrm{H}), 2.38(\mathrm{~s}, 3 \mathrm{H}) .{ }^{13} \mathrm{C} \mathrm{NMR}\left(75 \mathrm{MHz}, \mathrm{CDCl}_{3}\right) \delta 162.34,149.10,141.08,136.21,136.00,133.68$, $131.25,128.65,128.29,127.42,127.17,126.84,126.61,125.20,124.49,117.60,112.06,110.00,64.22$, 53.19, 28.26, 20.46. HRMS (ESI/TOF): $\mathrm{m} / \mathrm{z}$ calcd for $\mathrm{C}_{22} \mathrm{H}_{19} \mathrm{ClN}_{2} \mathrm{O}_{3}{ }^{+}[\mathrm{M}]^{+}, 394.1079$; found 394.1096.

2-((5-Bromoindolin-1-yl)(o-tolyl)methyl)-4-nitrophenol (6c): Obtained in $91 \%$ yield as an orange red solid. ${ }^{1} \mathrm{H}$ NMR $\left(300 \mathrm{MHz}, \mathrm{CDCl}_{3}\right) \delta 10.65$ (br. s, $1 \mathrm{H}$ ), 8.12 (dd, J=2.9, $\left.8.8 \mathrm{~Hz}, 1 \mathrm{H}\right), 7.88$ (d, J=2.9 Hz, $1 \mathrm{H}$ ), $7.35(\mathrm{~d}, \mathrm{~J}=7.6 \mathrm{~Hz}, 1 \mathrm{H}), 7.15-7.28(\mathrm{~m}, 4 \mathrm{H}), 7.09(\mathrm{dd}, \mathrm{J}=2.1,8.5 \mathrm{~Hz}, 1 \mathrm{H}), 6.97(\mathrm{~d}, \mathrm{~J}=8.8 \mathrm{~Hz}, 1 \mathrm{H}), 6.23(\mathrm{~d}$, $\mathrm{J}=8.8 \mathrm{~Hz}, 1 \mathrm{H}), 5.70(\mathrm{~s}, 1 \mathrm{H}), 3.23-3.31(\mathrm{~m}, 1 \mathrm{H}), 2.93-3.11(\mathrm{~m}, 3 \mathrm{H}), 2.38(\mathrm{~s}, 3 \mathrm{H}) .{ }^{13} \mathrm{C} \mathrm{NMR}\left(75 \mathrm{MHz}, \mathrm{CDCl}_{3}\right)$ $\delta 162.22,149.60,141.11,136.15,136.03,134.01,131.25,130.32,128.66,128.26,128.01,127.16$, $125.20,124.50,117.54,112.41,63.82,53.04,28.20,20.43$. HRMS (ESI/TOF): $\mathrm{m} / \mathrm{z}$ calcd for $\mathrm{C}_{22} \mathrm{H}_{20} \mathrm{BrN}_{2} \mathrm{O}_{3}{ }^{+}[\mathrm{M}+\mathrm{H}]^{+}, 439.0652$; found 439.0645 .

4-Nitro-2-((5-nitroindolin-1-yl)(o-tolyl)methyl)phenol (6d): Obtained in $85 \%$ yield as a dark red solid. ${ }^{1} \mathrm{H}$ NMR $\left(500 \mathrm{MHz}, \mathrm{DMSO}-\mathrm{d}_{6}\right) \delta 11.58(\mathrm{~s}, 1 \mathrm{H}), 8.15(\mathrm{dd}, \mathrm{J}=8.9,2.6 \mathrm{~Hz}, 1 \mathrm{H}), 7.91$ (dd, J=8.6, $\left.2.3 \mathrm{~Hz}, 1 \mathrm{H}\right)$, $7.87(\mathrm{~d}, \mathrm{~J}=1.1 \mathrm{~Hz}, 1 \mathrm{H}), 7.71(\mathrm{~d}, \mathrm{~J}=2.9 \mathrm{~Hz}, 1 \mathrm{H}), 7.27(\mathrm{~d}, \mathrm{~J}=4.0 \mathrm{~Hz}, 2 \mathrm{H}), 7.21-7.24(\mathrm{~m}, 1 \mathrm{H}), 7.15(\mathrm{~d}, \mathrm{~J}=7.4 \mathrm{~Hz}$, $1 \mathrm{H}), 7.08(\mathrm{~d}, \mathrm{~J}=8.6 \mathrm{~Hz}, 1 \mathrm{H}), 6.19(\mathrm{~s}, 1 \mathrm{H}), 6.17(\mathrm{~d}, \mathrm{~J}=9.2 \mathrm{~Hz}, 1 \mathrm{H}), 3.37-3.48(\mathrm{~m}, 3 \mathrm{H}), 3.06-3.16(\mathrm{~m}, 2 \mathrm{H})$, $2.15(\mathrm{~s}, 3 \mathrm{H}) .{ }^{13} \mathrm{C}$ NMR $\left(126 \mathrm{MHz}, \mathrm{DMSO}-\mathrm{d}_{6}\right) \delta 161.92,156.10,139.67,137.09,136.27,136.12,130.93$, $130.47,128.02$, 126.74, 126.50, 126.37, 125.86, 125.81, 124.35, 120.28, 115.85, 103.80, 54.66, 50.67, 26.25, 18.81. HRMS (ESI/TOF): $\mathrm{m} / \mathrm{z}$ calcd for $\mathrm{C}_{22} \mathrm{H}_{18} \mathrm{~N}_{3} \mathrm{O}_{5}{ }^{-}[\mathrm{M}-\mathrm{H}]^{-}$, 404.1252; found 404.1221.

1-((2-Hydroxy-5-nitrophenyl)(o-tolyl)methyl)indoline-4-carbonitrile (6e): Obtained with $98 \%$ yield as a pale yellow solid. ${ }^{1} \mathrm{H}$ NMR $\left(300 \mathrm{MHz}\right.$, Methanol- $\left.\mathrm{d}_{4}\right) \delta 8.10$ (dd, J=2.6, $\left.9.1 \mathrm{~Hz}, 1 \mathrm{H}\right), 7.96(\mathrm{~d}, \mathrm{~J}=2.3 \mathrm{~Hz}, 1 \mathrm{H})$, 7.14-7.22 (m, 4H), 6.95-7.01 (m, 2H), $6.79(\mathrm{~d}, \mathrm{~J}=7.6 \mathrm{~Hz}, 1 \mathrm{H}), 6.22(\mathrm{~d}, \mathrm{~J}=8.2 \mathrm{~Hz}, 1 \mathrm{H}), 6.06(\mathrm{~s}, 1 \mathrm{H}), 3.40$ (q, $\mathrm{J}=8.8 \mathrm{~Hz}, 1 \mathrm{H}), 3.25-3.33(\mathrm{~m}, 1 \mathrm{H}), 3.12-3.18(\mathrm{~m}, 2 \mathrm{H}), 2.23(\mathrm{~s}, 3 \mathrm{H}) .{ }^{13} \mathrm{C} \mathrm{NMR}\left(75 \mathrm{MHz}\right.$, Methanol- $\left.\mathrm{d}_{4}\right) \delta$ $162.84,153.10,141.85,138.44,137.82,135.75,131.83,129.58,128.87,128.80,128.50,127.25$, $126.10,125.95,120.22,118.68,116.28,111.02,109.14,57.13,51.71,28.58,19.45$. HRMS (ESI/TOF): $\mathrm{m} / \mathrm{z}$ calcd for $\mathrm{C}_{23} \mathrm{H}_{19} \mathrm{~N}_{3} \mathrm{O}_{3}{ }^{+}[\mathrm{M}]^{+}$, 385.1421; found 385.1427.

\subsection{Antibacterial Assays}

\subsubsection{Determination of MIC}

For selective purposes, the antimicrobial activity of the diverse compounds was preliminarily tested against seven bacterial Gram-positive strains obtained from American Type Culture Collection (ATCC): S. aureus ATCC 25923 (MSSA), S. aureus ATCC 6538 (MSSA), S. aureus CIP106760 (MRSA), E. faecalis ATCC 29212, E. faecalis ATCC 51299 (VRE), S. epidermidis ATCC 12228 and B. subtilis ATCC 6633 strains. For the most promising compounds (i.e., $\mathbf{1 d}$ and $\mathbf{5 a}$ ), the antimicrobial activity was further evaluated against eight distinct clinical isolates of S. aureus, S. epidermidis E. faecalis, E. faecium, and $L$. monocytogenes from the wide collection of pathogenic Gram-positive strains of the Portuguese National Institute of Health (NIH) (Supplementary Table 1).

Before each experiment, frozen stocks of all isolates were subcultured three times to check strain viability and to avoid any negative growth effect from congelation. S. aureus, S. epidermidis, E. faecalis, E. faecium and B. subtilis were subcultured in Mueller-Hinton (MH) agar at $35 \stackrel{\circ}{ } \mathrm{C}$ whereas $L$. monocytogenes was subcultured in $\mathrm{MH}$ agar supplemented with $5 \%$ defibrinated horse blood and $20 \mathrm{mg} / \mathrm{L} \beta-\mathrm{NAD}$ (MH-F) at $35^{\circ} \mathrm{C}$ in $5 \% \mathrm{CO}_{2}{ }^{52}$ 
For each compound, the minimum inhibitory concentration (MIC) was determined by the broth dilution method, ${ }^{53}$ according to the European Committee on Antimicrobial Susceptibility Testing (EUCAST) guidelines. ${ }^{52}$

Twofold serial dilutions of the concentrated stock compound solution (1 mM) were prepared in the required growth medium for each bacterial species into a 96-well plate. For ATCC strains, vancomycin was added as the positive control. Cation-Adjusted Mueller Hinton Broth (CAMHB, BD BBL) was used for S. aureus, S. epidermidis, E. faecalis, E. faecium ${ }^{52}$, and B. subtilis while CAMHB supplemented with $20 \mathrm{mg} / \mathrm{L} \beta$-NAD was used for $L$. monocytogenes. For all bacterial species, inocula of $1.5 \times 10^{8} \mathrm{CFU} / \mathrm{ml}$ (one for each strain/isolate) were prepared by direct colony saline-phosphate-buffered saline (PBS) suspension, equivalent to a $0.5 \mathrm{McF}$ arland standard, using colonies from the respective overnight agar plates. A 1:20 dilution of each prepared bacterial inoculum in the appropriate broth medium was subsequently used. Controls without the compound and bacterial inocula were also prepared. Plates were incubated for 16 to $24 \mathrm{~h}$ at $35^{\circ} \mathrm{C}$ (and with $5 \% \mathrm{CO}_{2}$ for L. monocytogenes). Purity check and colony or viable cell counts of the inoculum suspensions were also evaluated in order to ensure that the final inoculum density closely approximates the intended number. This was obtained by subculturing a diluted aliquot from the growth control-well (without compound) immediately after inoculation onto a suitable nonselective agar plate for simultaneous incubation. The MIC was determined as the lowest compound concentration at which no visible growth was observed. The bacterial growth was measured with an absorbance microplate reader (Thermo Scientific Multiskan FC, Loughborough, UK) set to $600 \mathrm{~nm}$. Assays were carried out in triplicate for each ATCC strain and in sextuplicate for each isolate.

\subsubsection{Determination of $M B C$}

After MIC assessment, MBC was also evaluated for each ATCC strain. Briefly, the bacterial suspension on the wells was homogenized, serial diluted, triplicate spread on appropriate medium, and incubated. The MBC attributed to the compound concentration resulting in a $99.9 \%$ reduction in bacterial numbers. All assays were carried out in triplicate for each tested microorganism.

\subsection{Toxicity evaluation}

\subsubsection{Brine Shrimp Lethality Bioassay (Artemia salina)}

For the most active antibacterial agents $(\mathbf{1 d}, \mathbf{5 a}, \mathbf{5 d}$, and $\mathbf{6 b}-\mathbf{d})$, the toxicity was evaluated using the Artemia salina model, as previously described. ${ }^{54}$ Each compound was tested at a fixed concentration of $10 \mathrm{ppm}$ in artificial seawater $(3.5 \% \mathrm{NaCl}$ solution) with $1 \% \mathrm{DMSO}(\mathrm{v} / \mathrm{v})$. Potassium dichromate $\left(\mathrm{K}_{2} \mathrm{Cr}_{2} \mathrm{O}_{7}\right)$ at $10 \mathrm{mg} / \mathrm{mL}$ was used as positive toxic control, while individual artificial seawater and DMSO (1\%) were included as negative controls. After $24 \mathrm{~h}$ of treatment, the number of survived larvae was recorded and the mortality rate (\%) was determined using the following equation:

$$
\text { Mortality rate }(\%)=\frac{\text { Total }_{\text {A.salina }}-\text { Alive }_{\text {A.salina }}}{\operatorname{Total}_{\text {A.salina }}} \times 100 \%
$$

where,

Total $_{\text {A. salina }}=$ the total number of larvae in the assay

Alive $_{\text {A. salina }}=$ the number of surviving $A$. salina larvae in the assay

The assay was carried out in triplicate for each tested compound.

\subsubsection{Saccharomyces cerevisiae Bioassay}

General toxicity studies using Saccharomyces cerevisiae (ATCC 2601) model were performed in a microdilution method adapted from a previous report. ${ }^{54}$ Briefly, a volume of $100 \mu \mathrm{L}$ was added to all the wells containing Sabouraud culture medium, and $100 \mu \mathrm{L}$ of the samples at a concentration of 1 $\mathrm{mg} / \mathrm{mL}$ were added to the first well. Serial dilutions were made in a proportion of 1:2 and $10 \mu \mathrm{L}$ of yeast suspension was added to each well. The plates were incubated for $24 \mathrm{~h}$ at $37^{\circ} \mathrm{C}$ and Optical Density at $525 \mathrm{~nm}$ was measured using a Microplate Reader (Thermo Scientific Multiskan FC, 
Loughborough, UK). Nystatin (NYS) was used as positive control and the assays were carried out in triplicate. Inhibition of cell growth was determined according to the formula:

$$
I C_{50}=100-\left[\frac{O D_{\text {sample }}-O D_{\text {medium control }}}{O D_{\text {cell control }}-O D \text { medium control }}\right] \times 100
$$

\subsubsection{MTT reduction assay}

\subsubsection{Cytotoxicity in HaCat cells}

The cytotoxicity assessment in the human keratinocyte HaCat cell line was carried out using the colorimetric MTT assay, as previously described. ${ }^{55}$ Briefly, $5 \times 10^{3}$ cells/well were seeded in $200 \mu \mathrm{L}$ of culture medium (Dulbecco's Modified Eagle's Medium supplemented with $10 \%$ fetal bovine serum, $100 \mathrm{U} / \mathrm{mL}$ penicillin and $0.1 \mathrm{mg} / \mathrm{mL}$ streptomycin in 96-well plates, and incubated at $37^{\circ} \mathrm{C}$ under an atmosphere with $5 \% \mathrm{CO}_{2}$ in air.

After $24 \mathrm{~h}$, cells were exposed to each compound at a final concentration of $50 \mu \mathrm{M}$ for a $24 \mathrm{~h}$-period. All compounds were initially solubilized in DMSO and then further diluted in PBS, so that the final concentration of DMSO in culture medium was $0.5 \%$ in all samples, except for the positive control (DMSO $5 \%(\mathrm{v} / \mathrm{v})$ ). After treatment, cells were washed with culture medium, followed by the addition of MTT $(0.5 \mathrm{mg} / \mathrm{mL})$. The cells were then incubated for a further $2.5 \mathrm{~h}$ period and carefully washed with PBS, prior to the DMSO addition ( $200 \mu \mathrm{L} /$ well) to solubilize the purple formazan crystals resultant from the MTT reduction by mitochondrial enzymes in metabolically active cells. The MTT reduction (proportional to the number of viable cells) was measured using an absorbance microplate reader (Thermo Scientific Multiskan FC, USA) set to $595 \mathrm{~nm}$. Two independent experiments were performed, each comprising four replicate cultures. Cytotoxicity results (mean \pm SD) were expressed as percentages relative to non-treated control cells.

\subsubsection{Cytotoxicity in MRC-5 cells}

The effects of increasing concentrations of each compound on MRC-5 cell (ATCC CCL-171) growth were tested in 96-well flat-bottomed microtiter plates. The cell line was purchased from LGC Promochem (Teddington, UK) and was cultured in Eagle's Minimal Essential Medium (EMEM) supplemented with non-essential amino acid mixture, a selection of vitamins, $10 \%$ heat-inactivated fetal bovine serum, 2 $\mathrm{mM}$ L-glutamine, $1 \mathrm{mM}$ Na-pyruvate, nystatin and penicillin-streptomycin mixture (Sigma-Aldrich, USA) in concentrations of $100 \mathrm{U} / \mathrm{L}$ and $10 \mathrm{mg} / \mathrm{L}$, respectively. The cell line was incubated at $37^{\circ} \mathrm{C}$, in a $5 \% \mathrm{CO}_{2}, 95 \%$ air atmosphere. Each compound was diluted in $100 \mu \mathrm{L}$ of EMEM medium. Then, $1.5 \times 10^{4}$ cells in $100 \mu \mathrm{L}$ of medium were added to each well, except for the medium control wells. The culture plates were further incubated at $37^{\circ} \mathrm{C}$ for $24 \mathrm{~h}$, prior to the addition of $20 \mu \mathrm{L}$ of MTT (Sigma-Aldrich, Spain) (from a $5 \mathrm{mg} / \mathrm{mL}$ stock solution) to each well. After incubation at $37^{\circ} \mathrm{C}$ for $4 \mathrm{~h}, 100 \mu \mathrm{L}$ of sodium dodecyl sulfate solution (Sigma-Aldrich, Spain) $(10 \%$ in $0.01 \mathrm{M} \mathrm{HCl})$ was added to each well and the plates were further incubated at $37^{\circ} \mathrm{C}$ overnight. Cell growth was determined by measuring the optical density (OD) at $540 \mathrm{~nm}$ (ref. $630 \mathrm{~nm}$ ) with a Multiscan EX ELISA reader. Inhibition of cell growth was determined according to formula (2) (see section 4.3.2). Results are expressed in terms of $\mathrm{IC}_{50}$, defined as the inhibitory dose that reduced the growth of the cells exposed to the tested compounds by $50 \%$, and presented as an average of 2 independent experiments and 4 replicates.

\subsection{Antioxidant Activity Evaluation (DPPH method)}

The antioxidant activity of compounds $\mathbf{1} \mathbf{d}$ and $\mathbf{5 a}$ was tested as previously described. ${ }^{30}$ Briefly, a concentration of $10 \mu \mathrm{g} / \mathrm{mL}(22-26 \mu \mathrm{M})$ of each compound was subjected to the free radical scavenging test (the DPPH method). The change in optical density (OD) of DPPH radicals was monitored at 517 $\mathrm{nm}$ against a corresponding blank. The antioxidant activity was calculated using the following equation:

$$
\text { Scavenging activity }(\%)=\frac{O D_{\text {control }}-O D_{\text {sample }}}{O D \text { control }} \times 100
$$

The reference standard used for this procedure was butylated hydroxytoluene (BHT). Tests were carried out in triplicate. 


\section{Acknowledgments}

Janne and Aatos Erkko Foundation, Academy of Finland (Decision 326487) and Fundação para a Ciência e Tecnologia (CEE-CINST/2018) are acknowledged for financial support. We thank Lijo George (Faculty of Engineering and Natural Sciences, TAU) for HRMS measurements.

\section{References}

(1) Theuretzbacher, U.; Outterson, K.; Engel, A.; Karlen, A. The Global Preclinical Antibacterial Pipeline. Nat. Rev. Microbiol. 2020, 18, 275. (10.1038/s41579-019-0288-0)

(2) Organization, W. H. Global Action Plan on Antimicrobial Resistance. https://apps.who.int/iris/bitstream/handle/10665/193736/9789241509763 eng.pdf?seque nce $=1$ (accessed 1 March 2021).

(3) Duval, R. E.; Grare, M.; Demore, B. Fight Against Antimicrobial Resistance: We Always Need New Antibacterials but for Right Bacteria. Molecules 2019, 24, 3152. (10.3390/molecules24173152)

(4) Santajit, S.; Indrawattana, N. Mechanisms of Antimicrobial Resistance in ESKAPE Pathogens. Biomed. Res. Int. 2016, DOI:10.1155/2016/2475067 10.1155/2016/2475067, 2475067. $(10.1155 / 2016 / 2475067)$

(5) Ma, Y. X.; Wang, C. Y.; Li, Y. Y.; Li, J.; Wan, Q. Q.; Chen, J. H.; Tay, F. R.; Niu, L. N. Considerations and Caveats in Combating ESKAPE Pathogens against Nosocomial Infections. Adv. Sci. 2020, 7, 1901872. (10.1002/advs.201901872)

(6) Agarwal, R.; Bartsch, S. M.; Kelly, B. J.; Prewitt, M.; Liu, Y.; Chen, Y.; Umscheid, C. A. Newer Glycopeptide Antibiotics for Treatment of Complicated Skin and Soft Tissue Infections: Systematic Review, Network Meta-analysis and Cost Analysis. Clin. Microbiol. Infect. 2018, 24, 361. (10.1016/j.cmi.2017.08.028)

(7) Blaskovich, M. A. T.; Hansford, K. A.; Butler, M. S.; Jia, Z.; Mark, A. E.; Cooper, M. A. Developments in Glycopeptide Antibiotics. ACS Infect. Dis. 2018, 4, 715. (10.1021/acsinfecdis.7b00258)

(8) Bouza, E.; Munoz, P.; Burillo, A. The Role of Tedizolid in Skin and Soft Tissue Infections. Curr. Opin. Infect. Dis. 2018, 31, 131. (10.1097/QCO.0000000000000439)

(9) Organization, W. H. Antibacterial Agents in Clinical Development. https://www.who.int/medicines/areas/rational use/antibacterial agents clinical developm ent/en/ (accessed 1 March 2021).

(10) Richter, M. F.; Hergenrother, P. J. The Challenge of Converting Gram-positive-only Compounds into Broad-spectrum Antibiotics. Ann. N. Y. Acad. Sci. 2019, 1435, 18. (10.1111/nyas.13598)

(11) David, M. Z.; Dryden, M.; Gottlieb, T.; Tattevin, P.; Gould, I. M. Recently Approved Antibacterials for Methicillin-resistant Staphylococcus aureus (MRSA) and Other Grampositive Pathogens: the Shock of the New. Int. J. Antimicrob. Agents 2017, 50, 303. (10.1016/j.ijantimicag.2017.05.006)

(12) Suleyman, G.; Alangaden, G.; Bardossy, A. C. The Role of Environmental Contamination in the Transmission of Nosocomial Pathogens and Healthcare-Associated Infections. Curr. Infect. Dis. Rep. 2018, 20, 12. (10.1007/s11908-018-0620-2)

(13) Bereket, W.; Hemalatha, K.; Getenet, B.; Wondwossen, T.; Solomon, A.; Zeynudin, A.; Kannan, S. Update on Bacterial Nosocomial Infections. Eur. Rev. Med. Pharmacol. Sci. 2012, 16, 1039.

(14) Silk, B. J.; McCoy, M. H.; Iwamoto, M.; Griffin, P. M. Foodborne Listeriosis Acquired in Hospitals. Clin. Infect. Dis. 2014, 59, 532. (10.1093/cid/ciu365)

(15) Gaul, L. K.; Farag, N. H.; Shim, T.; Kingsley, M. A.; Silk, B. J.; Hyytia-Trees, E. Hospital-Acquired Listeriosis Outbreak Caused by Contaminated Diced Celery - Texas, 2010. Clin. Infect. Dis. 2013, 56, 20. (10.1093/cid/cis817)

(16) Facciola, A.; Pellicano, G. F.; Visalli, G.; Paolucci, I. A.; Venanzi Rullo, E.; Ceccarelli, M.; D'Aleo, F.; Di Pietro, A.; Squeri, R.; Nunnari, G.et al. The Role of the Hospital Environment in the Healthcare-associated Infections: A General Review of the Literature. Eur. Rev. Med. Pharmacol. Sci. 2019, 23, 1266. (10.26355/eurrev_201902_17020)

(17) Miller, W. R.; Munita, J. M.; Arias, C. A. Mechanisms of Antibiotic Resistance in enterococci. Expert Rev. Anti Infect. Ther. 2014, 12, 1221. (10.1586/14787210.2014.956092) 
(18) Otto, M. Staphylococcal Biofilms. Curr. Top. Microbiol. Immunol. 2008, 322, 207. (10.1007/978-3-540-75418-3_10)

(19) Ch'ng, J. H.; Chong, K. K. L.; Lam, L. N.; Wong, J. J.; Kline, K. A. Biofilm-associated Infection by enterococci. Nat. Rev. Microbiol. 2019, 17, 82. (10.1038/s41579-018-0107-z)

(20) Lee, B. H.; Hebraud, M.; Bernardi, T. Increased Adhesion of Listeria monocytogenes Strains to Abiotic Surfaces under Cold Stress. Front. Microbiol. 2017, 8, 2221. (10.3389/fmicb.2017.02221)

(21) Roman, G. Mannich Bases in Medicinal Chemistry and Drug Design. Eur. J. Med. Chem. 2015, 89, 743. (10.1016/j.ejmech.2014.10.076)

(22) Roman, G.; Nastasa, V.; Bostanaru, A. C.; Mares, M. Antibacterial Activity of Mannich Bases Derived from 2-Naphthols, Aromatic Aldehydes and Secondary Aliphatic Amines. Bioorg. Med. Chem. Lett. 2016, 26, 2498. (10.1016/j.bmcl.2016.03.098)

(23) Doan, P.; Karjalainen, A.; Chandraseelan, J. G.; Sandberg, O.; Yli-Harja, O.; Rosholm, T.; Franzen, R.; Candeias, N. R.; Kandhavelu, M. Synthesis and Biological Screening for Cytotoxic Activity of $\mathrm{N}$-Substituted Indolines and Morpholines. Eur. J. Med. Chem. 2016, 120, 296. (10.1016/j.ejmech.2016.05.024)

(24) Doan, P.; Nguyen, T.; Yli-Harja, O.; Candeias, N. R.; Kandhavelu, M. Effect of Alkylaminophenols on Growth Inhibition and Apoptosis of Bone Cancer Cells. Eur. J. Pharm. Sci. 2017, 107, 208. (10.1016/j.ejps.2017.07.016)

(25) Karjalainen, A.; Doan, P.; Chandraseelan, J. G.; Sandberg, O.; Yli-Harja, O.; Candeias, N. R.; Kandhavelu, M. Synthesis of Phenol-derivatives and Biological Screening for Anticancer Activity. Anticancer Agents Med. Chem. 2017, 17, 1710. (10.2174/1871520617666170327142027)

(26) Doan, P.; Musa, A.; Candeias, N. R.; Emmert-Streib, F.; Yli-Harja, O.; Kandhavelu, M. Alkylaminophenol Induces G1/S Phase Cell Cycle Arrest in Glioblastoma Cells Through p53 and Cyclin-Dependent Kinase Signaling Pathway. Front. Pharmacol. 2019, 10, 330. (10.3389/fphar.2019.00330)

(27) Le, H. T. T.; Rimpilainen, T.; Konda Mani, S.; Murugesan, A.; Yli-Harja, O.; Candeias, N. R.; Kandhavelu, M. Synthesis and Preclinical Validation of Novel P2Y1 Receptor Ligands as a Potent Anti-prostate Cancer Agent. Sci. Rep. 2019, 9, 18938. (10.1038/s41598-019-55194-8)

(28) Gul, H. I.; Tugrak, M.; Gul, M.; Mazlumoglu, S.; Sakagami, H.; Gulcin, I.; Supuran, C. T. New Phenolic Mannich Bases with Piperazines and Their Bioactivities. Bioorg. Chem. 2019, 90, 103057. (10.1016/j.bioorg.2019.103057)

(29) Neto, I.; Andrade, J.; Fernandes, A. S.; Pinto Reis, C.; Salunke, J. K.; Priimagi, A.; Candeias, N. R.; Rijo, P. Multicomponent Petasis-borono Mannich Preparation of Alkylaminophenols and Antimicrobial Activity Studies. ChemMedChem 2016, 11, 2015. (10.1002/cmdc.201600244)

(30) Rimpilainen, T.; Andrade, J.; Nunes, A.; Ntungwe, E.; Fernandes, A. S.; Vale, J. R.; Rodrigues, J.; Gomes, J. P.; Rijo, P.; Candeias, N. R. Aminobenzylated 4-Nitrophenols as Antibacterial Agents Obtained from 5-Nitrosalicylaldehyde through a Petasis Borono-Mannich Reaction. ACS Omega 2018, 3, 16191. (10.1021/acsomega.8b02381)

(31) Candeias, N. R.; Montalbano, F.; Cal, P.; Gois, P. M. P. Boronic Acids and Esters in the PetasisBorono Mannich Multicomponent Reaction. Chemical Reviews 2010, 110, 6169. (10.1021/cr100108k)

(32) Wu, P.; Givskov, M.; Nielsen, T. E. Reactivity and Synthetic Applications of Multicomponent Petasis Reactions. Chem. Rev. 2019, 119, 11245. (10.1021/acs.chemrev.9b00214)

(33) Pham-Huy, L. A.; He, H.; Pham-Huy, C. Free Radicals, Antioxidants in Disease and Health. Int. J. Biomed. Sci. 2008, 4, 89.

(34) Di Meo, S.; Venditti, P. Evolution of the Knowledge of Free Radicals and Other Oxidants. Oxid. Med. Cell Longev. 2020, DOI:10.1155/2020/9829176 10.1155/2020/9829176, 9829176. (10.1155/2020/9829176)

(35) Nepali, K.; Lee, H. Y.; Liou, J. P. Nitro-Group-Containing Drugs. J. Med. Chem. 2019, 62, 2851. (10.1021/acs.jmedchem.8b00147)

(36) Van Norman, G. A. Limitations of Animal Studies for Predicting Toxicity in Clinical Trials: Is it Time to Rethink Our Current Approach? JACC Basic Transl. Sci. 2019, 4, 845. (10.1016/j.jacbts.2019.10.008) 
(37) Van Norman, G. A. Limitations of Animal Studies for Predicting Toxicity in Clinical Trials: Part 2: Potential Alternatives to the Use of Animals in Preclinical Trials. JACC Basic Transl. Sci. 2020, 5, 387. (10.1016/j.jacbts.2020.03.010)

(38) Freires, I. A.; Sardi, J. C.; de Castro, R. D.; Rosalen, P. L. Alternative Animal and Non-Animal Models for Drug Discovery and Development: Bonus or Burden? Pharm. Res. 2017, 34, 681. (10.1007/s11095-016-2069-z)

(39) Ntungwe, N. E.; Dominguez-Martin, E. M.; Roberto, A.; Tavares, J.; Isca, V. M. S.; Pereira, P.; Cebola, M. J.; Rijo, P. Artemia species: An Important Tool to Screen General Toxicity Samples. Curr. Pharm. Des. 2020, 26, 2892. (10.2174/1381612826666200406083035)

(40) Suarez-Diez, M.; Porras, S.; Laguna-Teno, F.; Schaap, P. J.; Tamayo-Ramos, J. A. Toxicological Response of the Model Fungus Saccharomyces cerevisiae to Different Concentrations of Commercial Graphene Nanoplatelets. Sci. Rep. 2020, 10, 3232. (10.1038/s41598-020-601017)

(41) Doke, S. K.; Dhawale, S. C. Alternatives to Animal Testing: A Review. Saudi Pharm. J. 2015, 23, 223. (10.1016/j.jsps.2013.11.002)

(42) Cronin, M. Non-animal approaches - The way forward. https://op.europa.eu/s/oM5H (accessed 1 March 2021).

(43) Buschini, A.; Poli, P.; Rossi, C. Saccharomyces cerevisiae as an Eukaryotic Cell Model to Assess Cytotoxicity and Genotoxicity of Three Anticancer Anthraquinones. Mutagenesis 2003, 18, 25. (10.1093/mutage/18.1.25)

(44) Libralato, G.; Prato, E.; Migliore, L.; Cicero, A. M.; Manfra, L. A Review of Toxicity Testing Protocols and Endpoints with Artemia spp. Ecol. Indic. 2016, 69, 35. (10.1016/j.ecolind.2016.04.017)

(45) Ermolli, M.; Menne, C.; Pozzi, G.; Serra, M. A.; Clerici, L. A. Nickel, Cobalt and Chromiuminduced Cytotoxicity and Intracellular Accumulation in Human Hacat Keratinocytes. Toxicology 2001, 159, 23. (10.1016/s0300-483x(00)00373-5)

(46) Gajdacs, M.; Spengler, G.; Sanmartin, C.; Marc, M. A.; Handzlik, J.; Dominguez-Alvarez, E. Selenoesters and Selenoanhydrides as Novel Multidrug Resistance Reversing Agents: A Confirmation Study in a Colon Cancer MDR Cell Line. Bioorg. Med. Chem. Lett. 2017, 27, 797. (10.1016/j.bmcl.2017.01.033)

(47) Zhang, L.; Qiu, R.; Xue, X.; Pan, Y.; Xu, C.; Li, H.; Xu, L. Versatile (Pentamethylcyclopentadienyl)rhodium-2,2'-Bipyridine (Cp*Rh-bpy) Catalyst for Transfer Hydrogenation of N-Heterocycles in Water. Adv. Synth. Catal. 2015, 357, 3529. (10.1002/adsc.201500491)

(48) Li, D. D.; Chen, Y. M.; Ma, M. Y.; Yu, Y. L.; Jia, Z. Z.; Li, P. H.; Xie, Z. Y. Regioselective C5 Nitration of $\mathrm{N}$-Protected Indolines Using Ferric Nitrate Under Mild Conditions. Synth. Commun. 2019, 49, 1231. (10.1080/00397911.2019.1580745)

(49) Piatnitski Chekler, E. L.; Unwalla, R.; Khan, T. A.; Tangirala, R. S.; Johnson, M.; St Andre, M.; Anderson, J. T.; Kenney, T.; Chiparri, S.; McNally, C.et al. 1-(2-Hydroxy-2-methyl-3phenoxypropanoyl)indoline-4-carbonitrile derivatives as potent and tissue selective androgen receptor modulators. J. Med. Chem. 2014, 57, 2462. (10.1021/jm401625b)

(50) Chaofeng, L.; Zhengxia, C.; Xiaoxin, C.; Yang, Z.; Zhuowei, L.; Peng, L.; Shuhui, C.; Guibai, L.; Cheng, X.; Zhenwei, L.et al., Tyrosine Kinase Inhibitor and Pharmaceutical Composition Comprising Same, EP3293177 2016.

(51) Di Donato, M.; Lerch, M. M.; Lapini, A.; Laurent, A. D.; lagatti, A.; Bussotti, L.; Ihrig, S. P.; Medved, M.; Jacquemin, D.; Szymanski, W.et al. Shedding Light on the Photoisomerization Pathway of Donor-Acceptor Stenhouse Adducts. J. Am. Chem. Soc. 2017, 139, 15596. (10.1021/jacs.7b09081)

(52) The European Committee on Antimicrobial Susceptibility Testing. Breakpoint tables for interpretation of MICs and zone diameters. Version 11.0, 2021. http://www.eucast.org (accessed 1 March 2021).

(53) Wiegand, I.; Hilpert, K.; Hancock, R. E. Agar and Broth Dilution Methods to Determine the Minimal Inhibitory Concentration (MIC) of Antimicrobial Substances. Nat. Protoc. 2008, 3, 163. (10.1038/nprot.2007.521) 
(54) Frija, L. M. T.; Ntungwe, E.; Sitarek, P.; Andrade, J. M.; Toma, M.; Sliwinski, T.; Cabral, L.; ML, S. C.; Rijo, P.; Pombeiro, A. J. L. In Vitro Assessment of Antimicrobial, Antioxidant, and Cytotoxic Properties of Saccharin-Tetrazolyl and -Thiadiazolyl Derivatives: The Simple Dependence of the pH Value on Antimicrobial Activity. Pharmaceuticals 2019, 12. (10.3390/ph12040167)

(55) Wagemaker, T. A.; Rijo, P.; Rodrigues, L. M.; Maia Campos, P. M.; Fernandes, A. S.; Rosado, C. Integrated Approach in the Assessment of Skin Compatibility of Cosmetic Formulations with Green Coffee Oil. Int. J. Cosmet. Sci. 2015, 37, 506. (10.1111/ics.12225) 